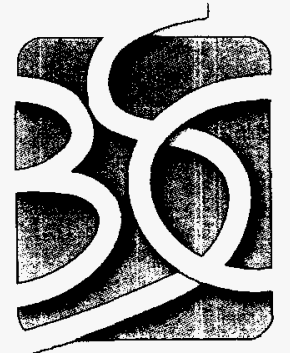

BECHTEL SAIC COMPAN LC

\title{
TRANSPORT LOCOMOTIVE AND WASTE PACKAGE TRANSPORTER ITS STANDARDS IDENTIFICATION STUDY
}

Prepared for:

U.S. Department of Energy

Office of Civilian Radioactive Waste Management

Office of Repository Development

1551 Hillshire Drive

Las Vegas, Nevada 89134-6321

Prepared by:

Bechtel SAIC Company, LLC

1180 Town Center Drive

Las Vegas, Nevada 89144

Under Contract Number

DE-AC28-01RW12101 


\section{DISCLAIMER}

This report was prepared as an account of work sponsored by an agency of the United States Government. Neither the United States Government nor any agency thereof, nor any of their employees, nor any of their contractors, subcontractors or their employees, makes any warranty, express or implied, or assumes any legal liability or responsibility for the accuracy, completeness, or any third party's use or the results of such use of any information, apparatus, product, or process disclosed, or represents that its use would not infringe privately owned rights. Reference herein to any specific commercial product, process, or service by trade name, trademark, manufacturer, or otherwise, does not necessarily constitute or imply its endorsement, recommendation, or favoring by the United States Government or any agency thereof or its contractors or subcontractors. The views and opinions of authors expressed herein do not necessarily state or reflect those of the United States Government or any agency thereof. 
QA: N/A

BSC ENGINEERING STUDY

(800-30R-HE00-00400-000-000)

REV 000

March 2005

\section{TRANSPORT LOCOMOTIVE AND WASTE PACKAGE TRANSPORTER ITS STANDARDS IDENTIFICATION}

Prepared by:

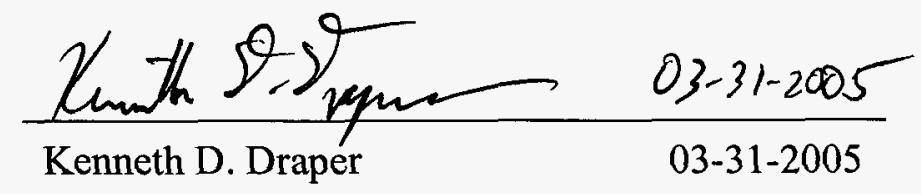

Reviewed by:

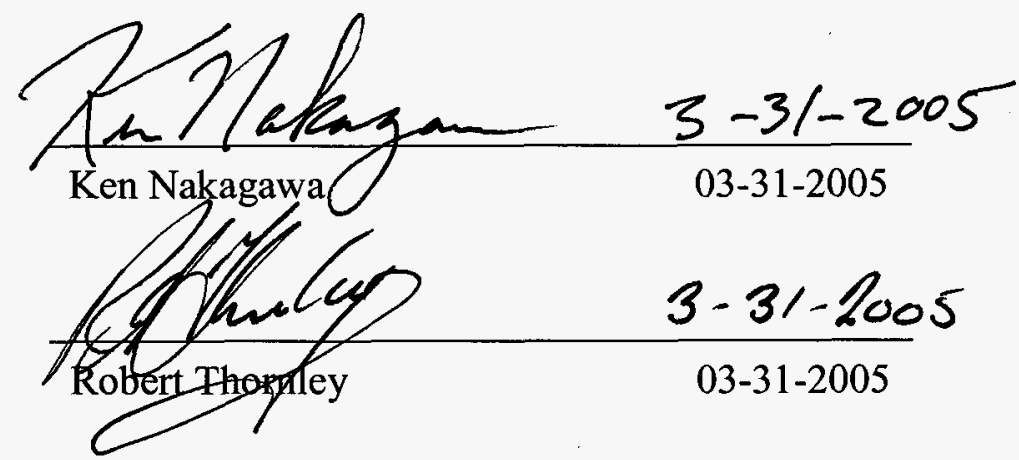

Approved by Project Engineer or Responsible Manager (if required)

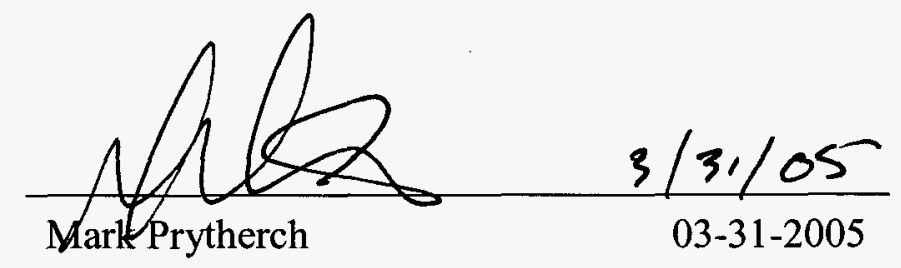


INTENTIONALLY LEFT BLANK 


\section{CONTENTS}

Page

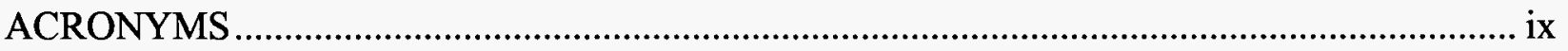

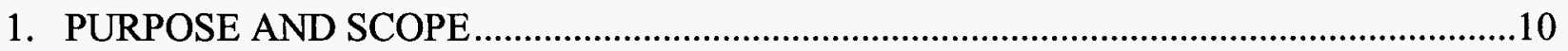

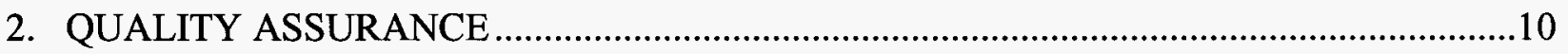

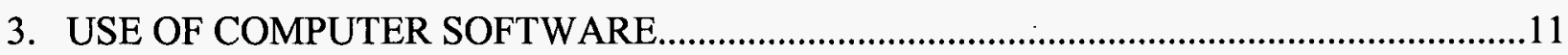

4. TRANSPORT LOCOMOTIVE AND WP TRANSPORTER FUNCTIONAL

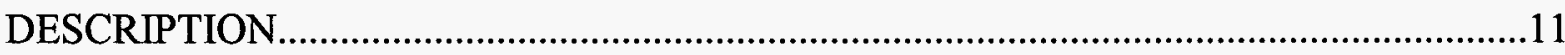

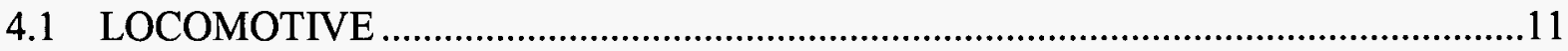

4.1.1 Transport Locomotive Basic Control System......................................................12

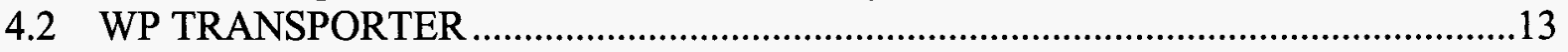

4.2.1 WP Transporter Basic Control System ..............................................................13

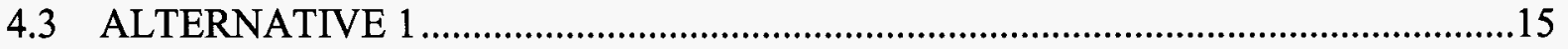

4.3.1 Transport Locomotive Basic Control System .....................................................15

4.3.2 WP Transporter Basic Control System ........................................................16

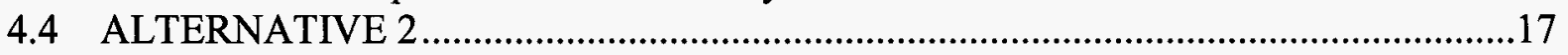

4.4.1 Transport Locomotive Basic Control System........................................................17

4.4.2 WP Transporter Basic Control System .............................................................18

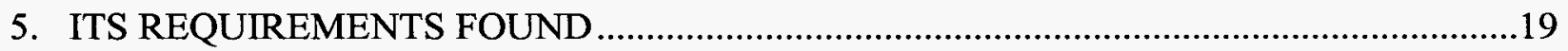

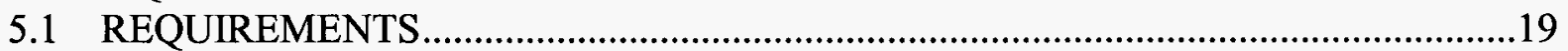

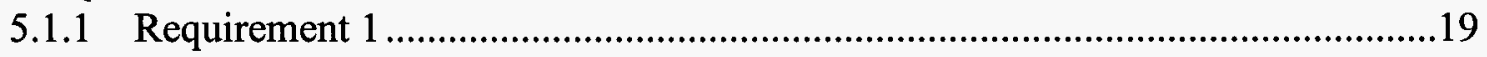

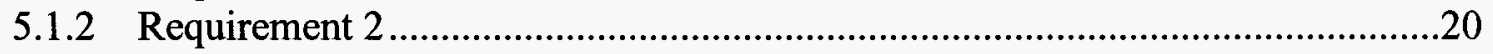

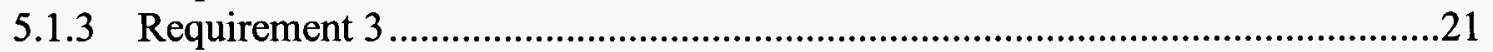

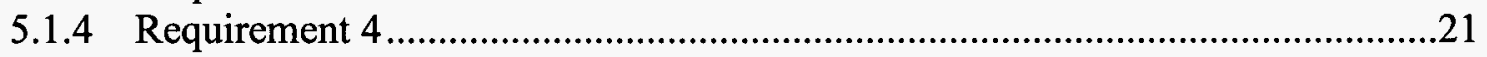

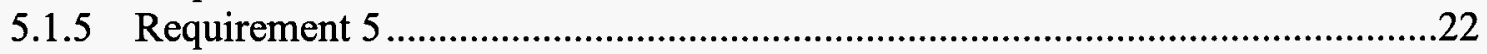

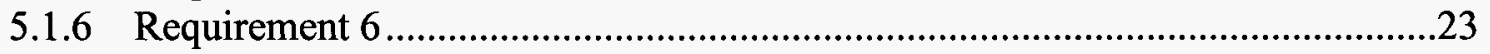

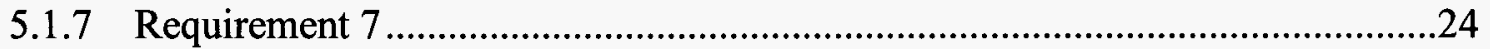

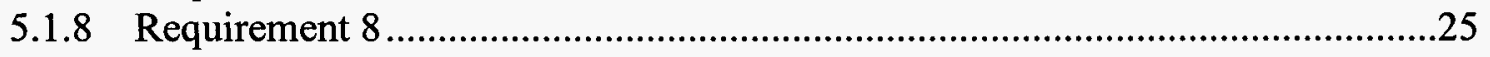

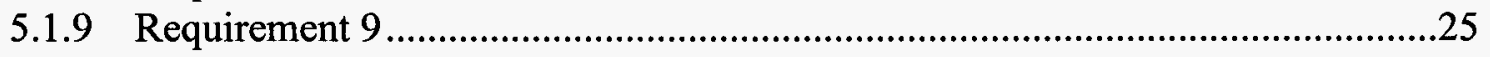

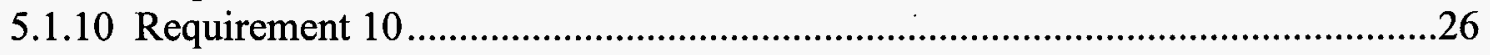

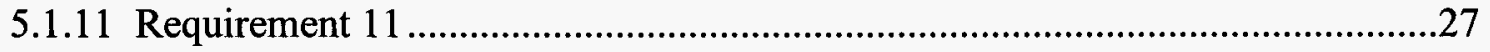

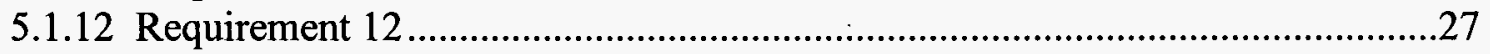

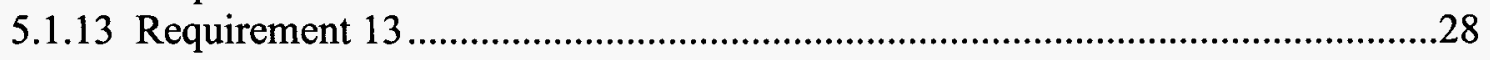

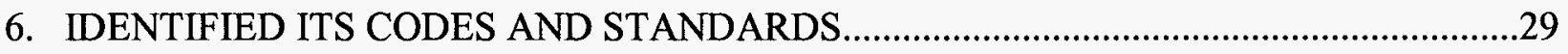

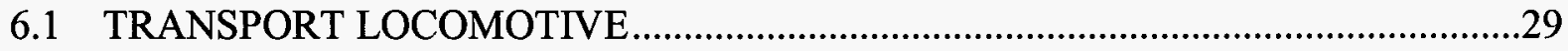

6.1.1 Transport Locomotive Control System............................................................29

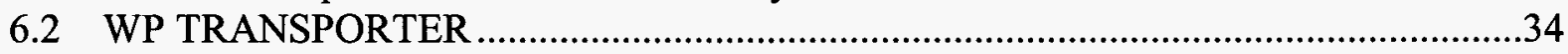

6.2.1 WP Transporter Control System (TCS) ..............................................................

6.2.2 Transporter Shielded Doors and Compartment …................................................44

6.2.3 Suspension Design ...............................................................................................44 


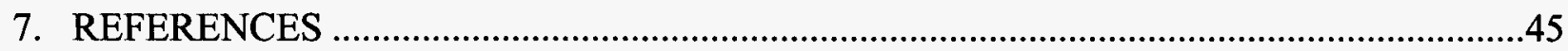

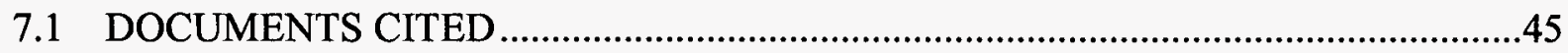

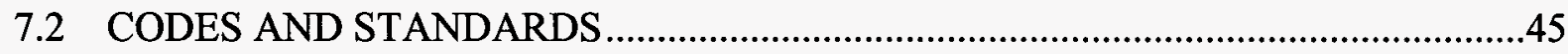

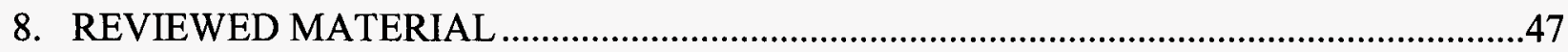

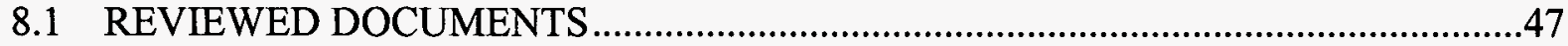

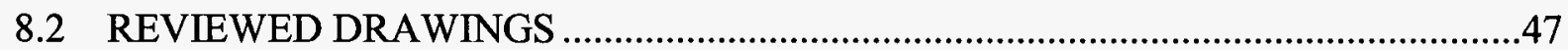

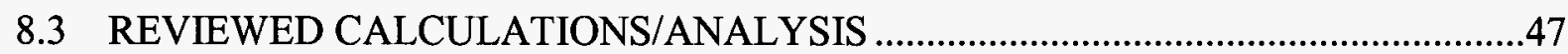

8.4 REVIEWED SYSTEM DESCRIPTION DOCUMENT ...........................................48

8.5 REVIEWED INDUSTRY CODES AND STANDARDS............................................

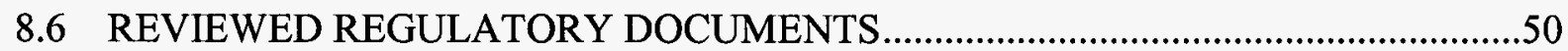

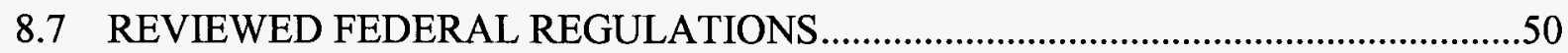

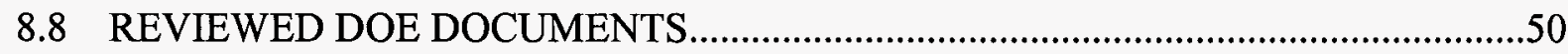




\section{FIGURES}

Page

Figure 4.1.1-1: Transport Locomotive Basic Control Block Diagram ................................... 12

Figure 4.2.1-1: WP Transporter Basic Control Block Diagram ........................................... 14

Figure 4.3.1-1: Alternative 1 Transport Locomotive Basic Control Block Diagram ................... 15

Figure 4.3.2-1: Alternative 1 WP Transporter Basic Control Block Diagram ........................... 16

Figure 4.4.1-1: Alternative 2 Transport Locomotive Basic Control Block Diagram ................... 17

Figure 4.4.2-1: Alternative 2 WP Transporter Basic Control Block Diagram .......................... 18 


\section{TABLES}

Page

Table 5.1.1-1: Transport Locomotive Identified ITS Functions.................................................... 20

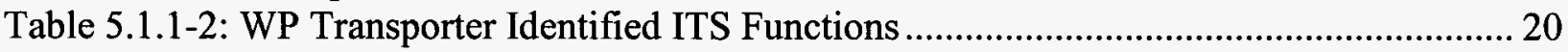

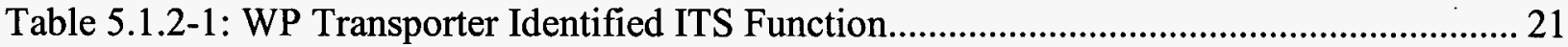

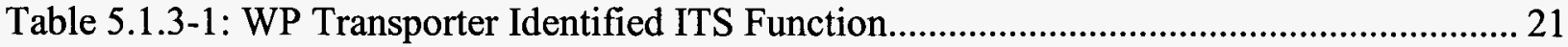

Table 5.1.4-1: Transport Locomotive Identified ITS Functions............................................... 22

Table 5.1.4-2: WP Transporter Identified ITS Functions ........................................................... 22

Table 5.1.5-1: Transport Locomotive Identified ITS Functions................................................. 23

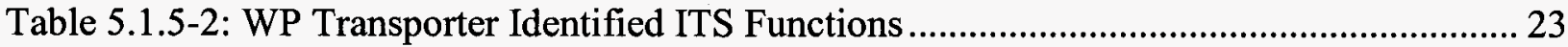

Table 5.1.6-1: Transport Locomotive Identified ITS Functions................................................... 24

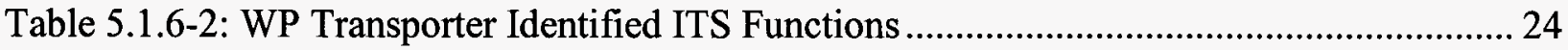

Table 5.1.7-1: WP Transporter Identified ITS Function.............................................................. 25

Table 5.1.8-1: WP Transporter Identified ITS Function................................................................. 25

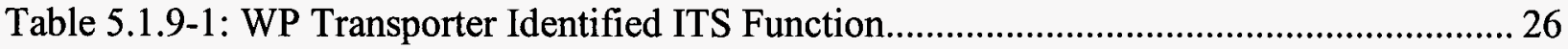

Table 5.1.10-1: WP Transporter Identified ITS Function............................................................ 26

Table 5.1.11-1: WP Transporter Identified ITS Function...................................................... 27

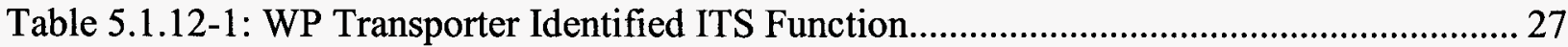

Table 5.1.13-1: Transport Locomotive Identified ITS Functions................................................ 28

Table 5.1.13-2: WP Transporter Identified ITS Functions ..................................................... 28

Table 6.1.1-1: Transport Locomotive Control System Applicable Codes and Standards ............. 30

Table 6.1.1-2: Transport Locomotive Speed Control System Applicable Codes and Standards . 31

Table 6.1.1-3: Transport Locomotive Brake Control System Applicable Codes and Standards . 32

Table 6.1.1-4: Pneumatic Tread Brake Subsystem Applicable Codes and Standards................... 33

Table 6.1.1-5: Disc Brake Subsystem Applicable Codes and Standards......................................... 33

Table 6.1.1-6: Transport Locomotive Coupler Applicable Codes and Standards .......................... 34

Table 6.2.1-1: WP Transporter Control System Applicable Codes and Standards ....................... 35

Table 6.2.1-2: Braking Control System Applicable Codes and Standards ..................................... 36

Table 6.2.1-3: Pneumatic Tread Brake Subsystem Applicable Codes and Standards................... 37

Table 6.2.1-4: Disc Brake Subsystem Applicable Codes and Standards........................................ 37

Table 6.2.1-5: WP Transporter Coupler Applicable Codes and Standards .................................... 38

Table 6.2.1-6: Bedplate Control System Applicable Codes and Standards.................................... 39

Table 6.2.1-7: Bedplate Locking Mechanism Applicable Codes and Standards............................. 39

Table 6.2.1-8: Bedplate Position Sensor Applicable Codes and Standards..................................... 40

Table 6.2.1-9: Shield Door Control System Applicable Codes and Standards .............................. 40

Table 6.2.1-10: Shield Door Locking Mechanism Applicable Codes and Standards .................... 41

Table 6.2.1-11: Shield Door Hinges Applicable Codes and Standards ........................................... 41

Table 6.2.1-12: Shield Door Position Sensor Applicable Codes and Standards ........................... 41

Table 6.2.1-13: Position Control System Applicable Codes and Standards.................................. 42

Table 6.2.1-14: Position Sensor Applicable Codes and Standards ................................................ 43

Table 6.2.1-15: Radiation Detector Sensor Applicable Codes and Standards............................... 43

Table 6.2.2-1: Shielded Doors and Compartment Applicable Codes and Standards .................... 44

Table 6.2.3-1: Suspension Design Applicable Codes and Standards ............................................. 45 


\section{ACRONYMS}

$\begin{array}{ll}\text { AAR } & \text { American Association of Railroads } \\ \text { BDBGM } & \text { beyond design base ground motion } \\ \text { BSC } & \text { Bechtel SAIC Company, LLC } \\ \text { BPCS } & \text { bedplate control system } \\ \text { DBGM } & \text { design base ground motion } \\ \text { DOE } & \text { Department of Energy } \\ \text { ECP } & \text { electronically controlled pneumatic } \\ \text { FCS } & \text { facility control system } \\ \text { HLRM } & \text { high level radioactive material } \\ \text { ITS } & \text { important to safety } \\ \text { LCS } & \text { locomotive control system } \\ \text { LBCS } & \text { locomotive brake control system } \\ \text { MCS } & \text { main control system } \\ \text { MT } & \text { metric ton } \\ \text { NITS } & \text { non-important to safety } \\ \text { NSDB } & \text { Nuclear Safety Design Basis } \\ \text { PCS } & \text { position control system } \\ \text { SCS } & \text { speed control system } \\ \text { SSC } & \text { structures, systems and components } \\ \text { SDCS } & \text { shield door control system } \\ \text { TCS } & \text { transporter control system } \\ \text { TBCS } & \text { transporter brake control system } \\ \text { WP } & \text { waste package } \\ & \end{array}$




\section{PURPOSE AND SCOPE}

To date, the project has established important to safety (ITS) performance requirements for structures, systems and components (SSCs) based on identification and categorization of event sequences that may result in a radiological release. These performance requirements are defined within the Nuclear Safety Design Basis for License Application (NSDB) (BSC 2005). Further, SSCs credited with performing safe functions are classified as ITS. In turn, performance confirmation for these SSCs is sought through the use of consensus code and standards.

The purpose of this study is to identify applicable codes and standards for the waste package (WP) transporter and transport locomotive ITS SSCs. Further, this study will form the basis for selection and the extent of applicability of each code and standard.

This study is based on the design development completed for License Application only. Accordingly, identification of ITS SSCs beyond those defined within the NSDB are based on designs that may be subject to further development during detail design. Furthermore, several design alternatives may still be under consideration to satisfy certain safety functions, and that final selection will not be determined until further design development has occurred. Therefore, for completeness, throughout this study alternative designs currently under consideration will be discussed. Further, the results of this study will be subject to evaluation as part of a follow-on gap analysis study.

Based on the results of this study the gap analysis will evaluate each code and standard to ensure each ITS performance requirement is fully satisfied. When a performance requirement is not fully satisfied a "gap" is highlighted. Thereafter, the study will identify supplemental requirements to augment the code or standard to meet performance requirements. Further, the gap analysis will identify non-standard areas of the design that will be subject to a Development Plan. Non-standard components and non-standard design configurations are defined as areas of the design that do not follow standard industry practices or codes and standards. Whereby, performance confirmation can not be readily sought through use of consensus standards.

In order for this to be accomplished, a control schematic will be developed to correlate with the baseline configuration presented in the Waste Package Transporter Preclosure Safety Analysis (BSC 2004).

The study contained in this document has been developed by Design \& Engineering / Mechanical Handling in its work regarding ITS codes and standards identification for the Emplacement and Retrieval. Yucca Mountain Project personnel from Design \& Engineering / Mechanical Handling should be consulted before use of the study for purposes other than those stated herein or used by individuals other than authorized personnel in Design \& Engineering / Mechanical Handling.

\section{QUALITY ASSURANCE}

This document was prepared in accordance with LP-ENG-014-BSC, Engineering Studies. The results of this document are only to be used as the basis for selection of applicable codes and 
standards and are not to be used directly to generate quality products. Therefore, this engineering study is not subject to requirements of the Quality Assurance Requirements and Description document (DOE 2004).

\section{USE OF COMPUTER SOFTWARE}

Computer software used, Microsoft Word 1997, in this study is classified as exempt from procedure LP-SI.11Q-BSC, Software Management. All software used to prepare this analysis is listed under Section 2.1 Software Not Subject To This Procedure, of LP-SI.11Q-BSC, Software Management.

\section{TRANSPORT LOCOMOTIVE AND WP TRANSPORTER FUNCTIONAL DESCRIPTION}

Before these ITS Codes and standards can be identified, a basic control block diagram needs to be developed to correlate with the baseline configuration presented in the Waste Package Transporter Preclosure Safety Analysis. Within the Waste Package Transporter Preclosure Safety Analysis, a fault tree analysis was performed with two possible alternatives that meet the necessary reliability. Alternative 1 is a single-channel dynamic brake in conjunction with the basic service brake system (BSC 2004, Section 6.8.2). Alternative 2 is a single-channel independent brake in conjunction with the basic service brake system (BSC 2004, Section 6.8.3).

\subsection{LOCOMOTIVE}

The primary function of the transport locomotive is to move the WP transporter and other railbased support equipment utilized by the emplacement and retrieval system, such as the gantry carrier and WP transporter. 


\subsubsection{Transport Locomotive Basic Control System}

Figure 4.1.1-1 depicts a generalized control block diagram of LCS interface with the following systems and components:

- main control system (MCS)

- locomotive control system (LCS)

- speed control system (SCS)

- transporter control system (TCS)

- locomotive brake control system (LBCS)

- coupler (connects to the WP transporter)
- drive system

- speed sensor

- dynamic brake

- pneumatic tread brake system

- disc brake system

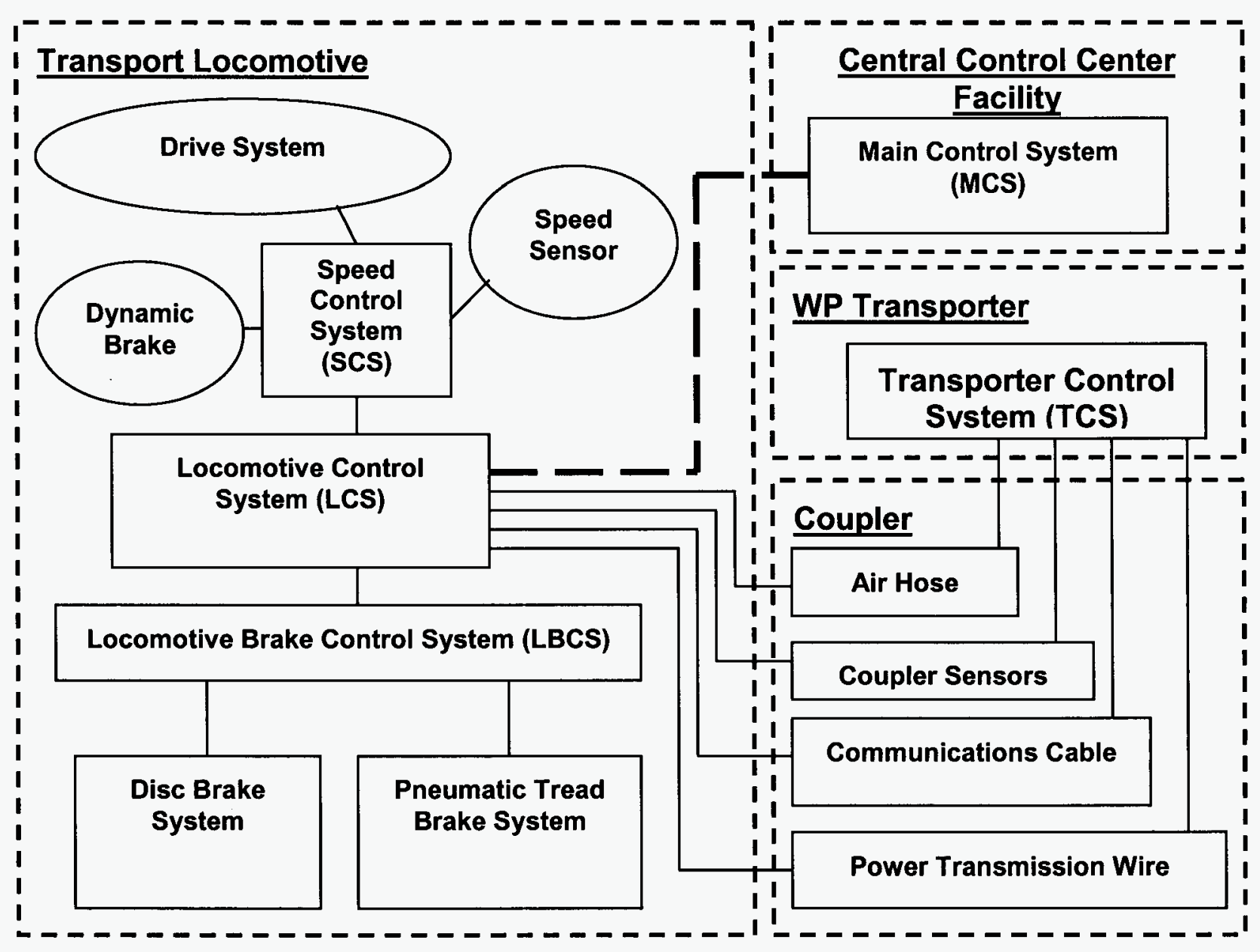

Figure 4.1.1-1: Transport Locomotive Basic Control Block Diagram 


\subsection{WP TRANSPORTER}

The primary function of the WP transporter is to safely transport waste packages between the Surface Facilities and the emplacement transfer docks for both emplacement and retrieval operations. The transport locomotive provides the motive force for all movements of the waste package transporter. The transporter primarily consists of a radiological shielded enclosure (with bedplate) mounted to a railcar.

\subsubsection{WP Transporter Basic Control System}

Figure 4.2.1-1 depicts a generalized control block diagram of the TCS interface with the following systems and components:

- facility control system (FCS)

- transporter control system (TCS)

- locomotive control system (LCS)

- position control system (PCS)

- bedplate control system (BPCS)

- shield door control system (SDCS)

- transporter brake control system (TBCS)

- coupler (connects to the transport - shield door locking mechanism locomotive)

- Position Detector
- radiation detection sensor

- pneumatic tread brake system

- disc brake system

- bedplate position sensor

- bedplate drive system

- bedplate locking mechanism

- shield door position sensor

- shield door drive mechanism 


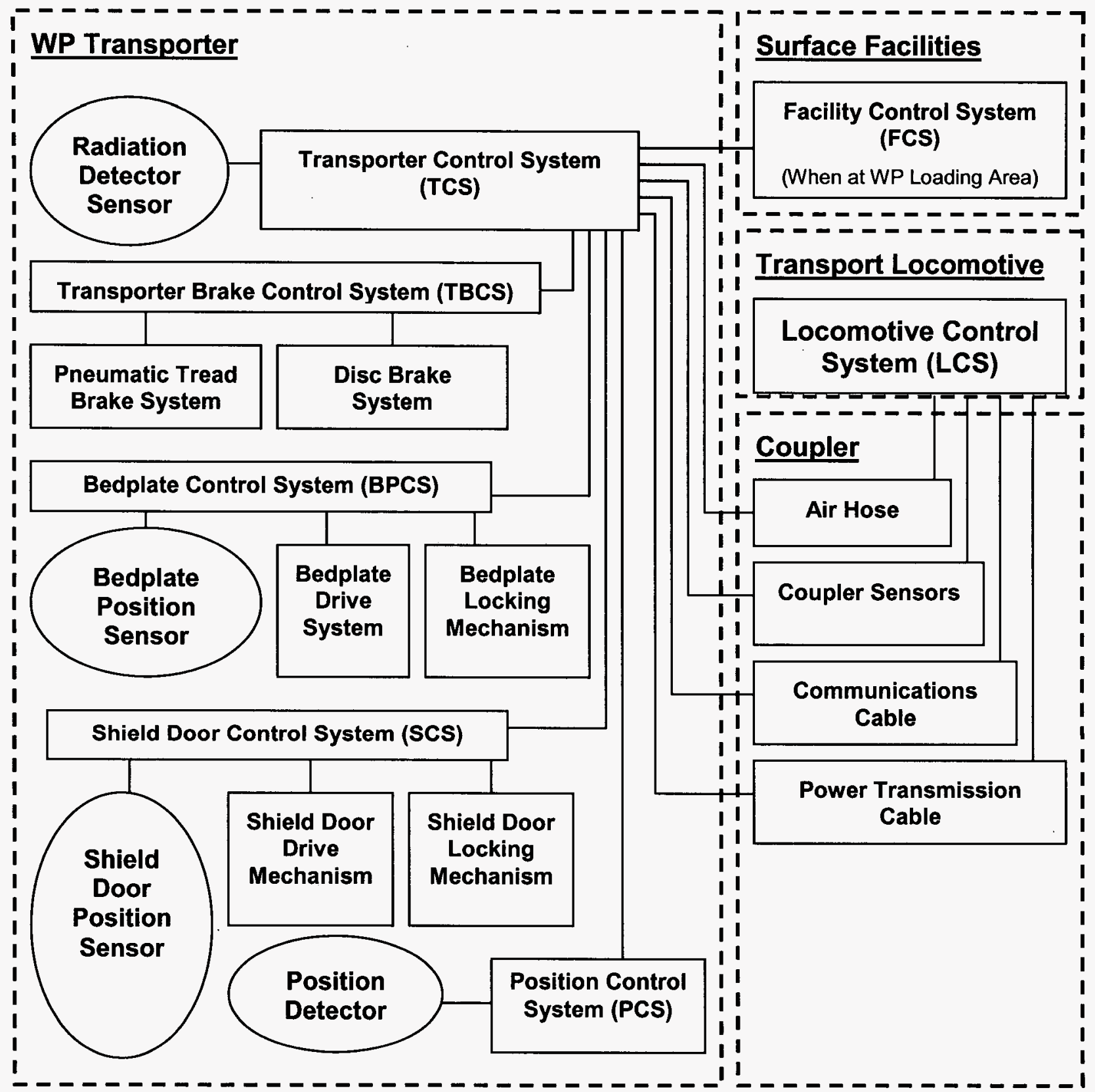

Figure 4.2.1-1: WP Transporter Basic Control Block Diagram 


\subsection{ALTERNATIVE 1}

Alternative 1 is a single-channel dynamic brake in conjunction with the basic service brake system (BSC 2004, Section 6.8.2).

\subsubsection{Transport Locomotive Basic Control System}

Figure 4.3.1-1 represents the transport locomotive basic control system (for alternative 1) with the systems and components identified as ITS or NITS.

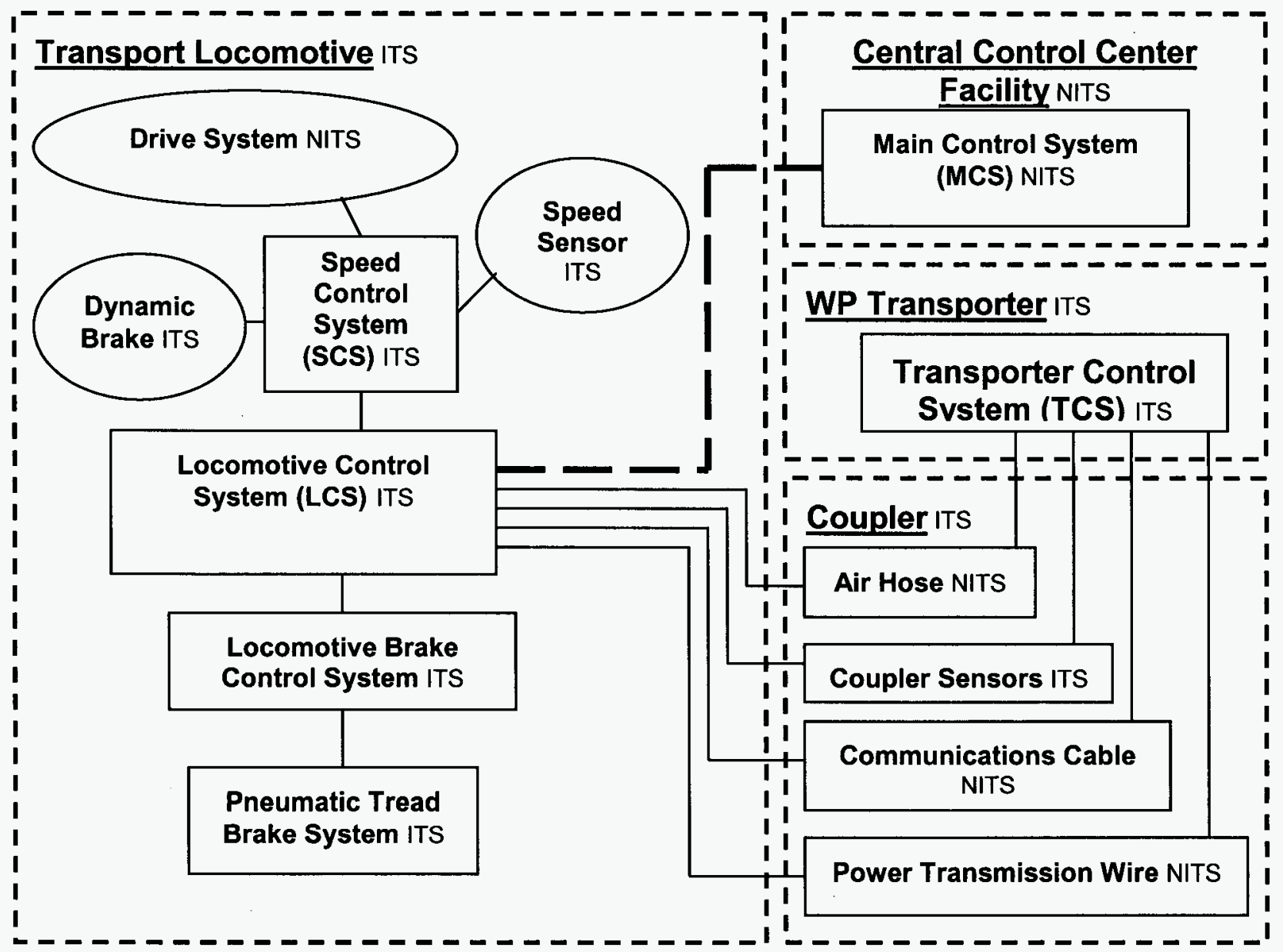

Figure 4.3.1-1: Alternative 1 Transport Locomotive Basic Control Block Diagram 


\subsubsection{WP Transporter Basic Control System}

Figure 4.3.2-1 represents the WP transporter basic control system (for alternative 1) with the systems and components identified as ITS or NITS.

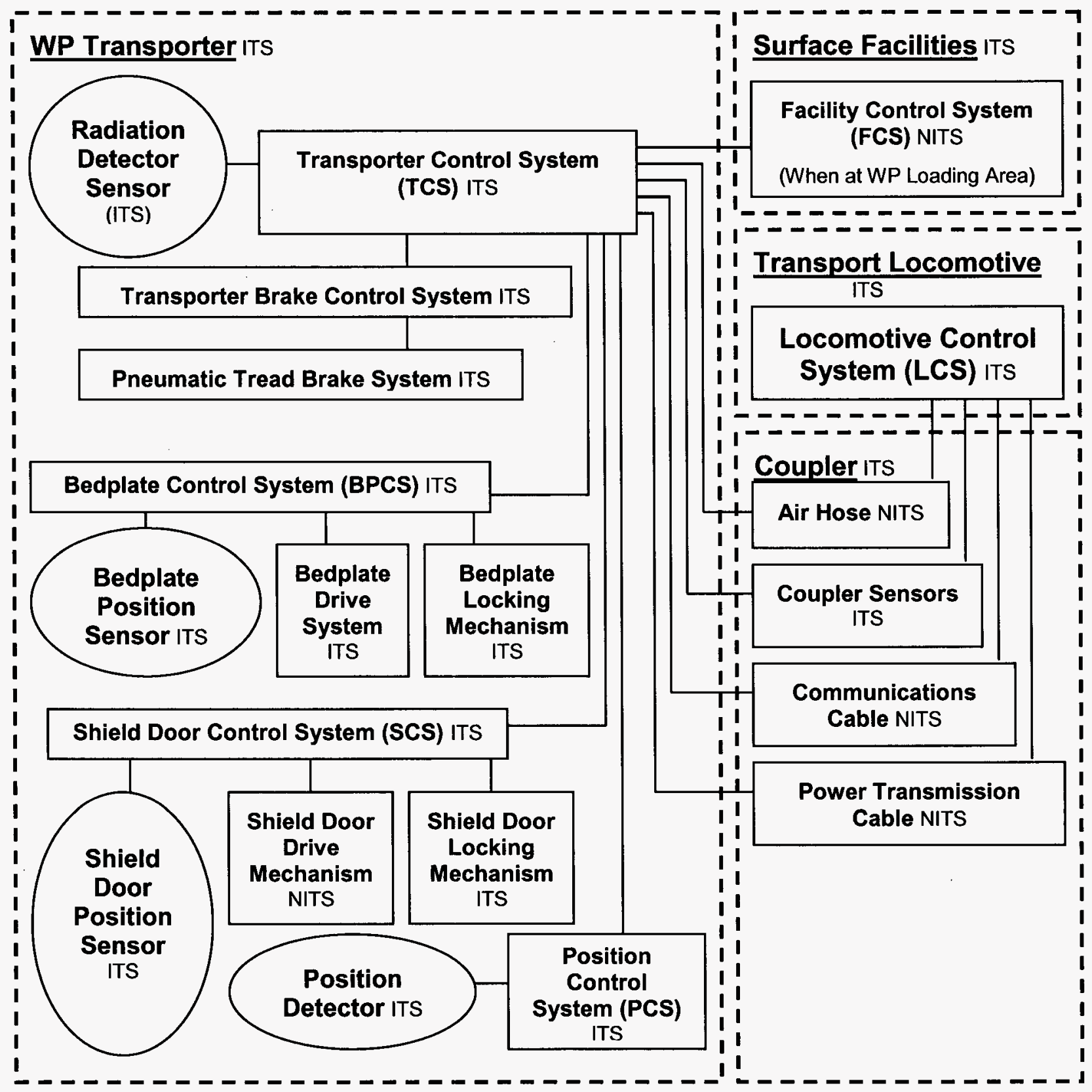

Figure 4.3.2-1: Alternative 1 WP Transporter Basic Control Block Diagram 


\subsection{ALTERNATIVE 2}

Alternative 2 is a single-channel independent brake in conjunction with the basic service brake system (BSC 2004, Section 6.8.3).

\subsubsection{Transport Locomotive Basic Control System}

Figure 4.4.1-1 represents the transport locomotive basic control system (for alternative 2) with the systems and components identified as ITS or NITS.

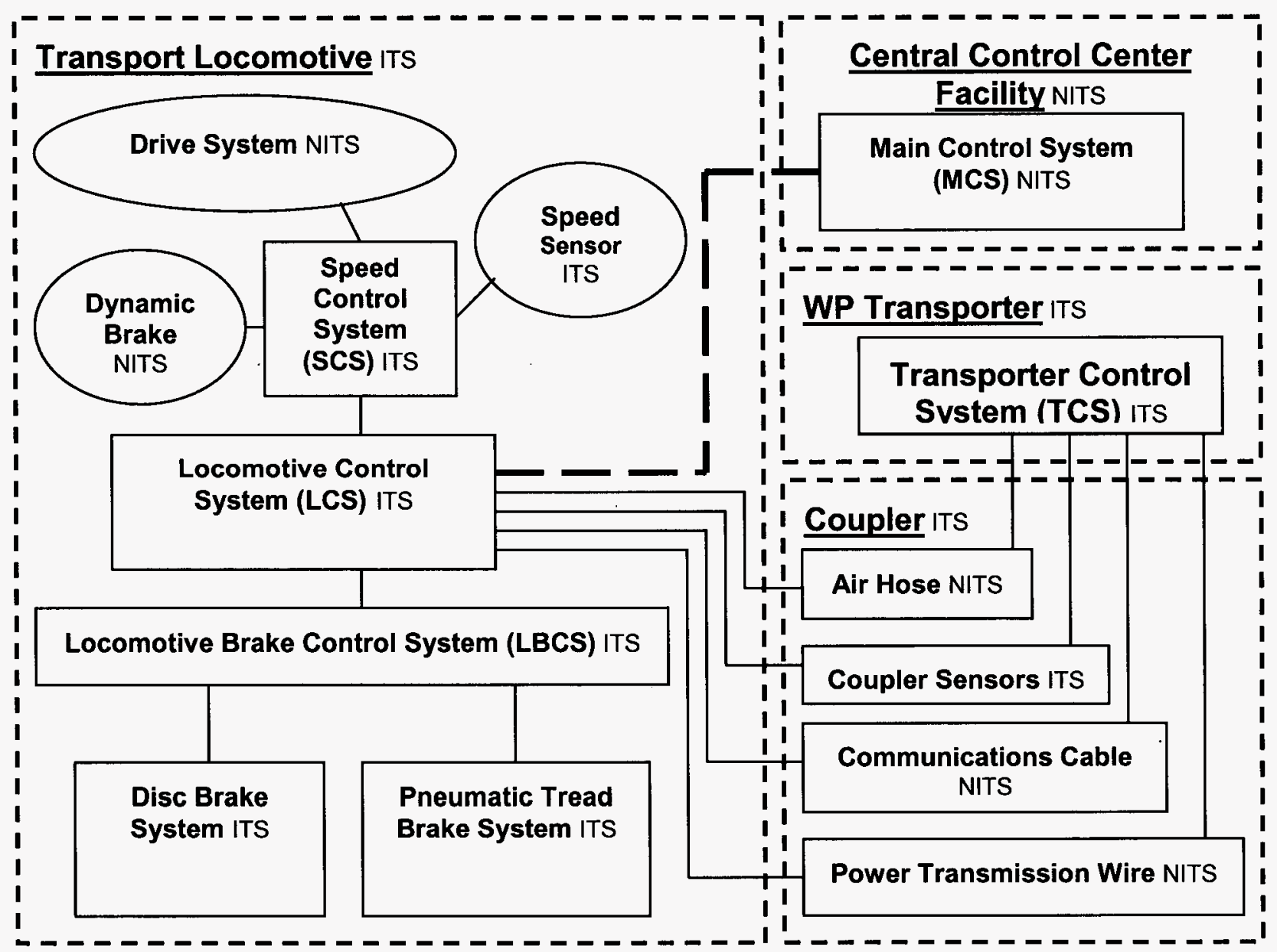

Figure 4.4.1-1: Alternative 2 Transport Locomotive Basic Control Block Diagram 


\subsubsection{WP Transporter Basic Control System}

Figure 4.4.2-1 represents the WP transporter basic control system (for alternative 2) with the systems and components identified as ITS or NITS.

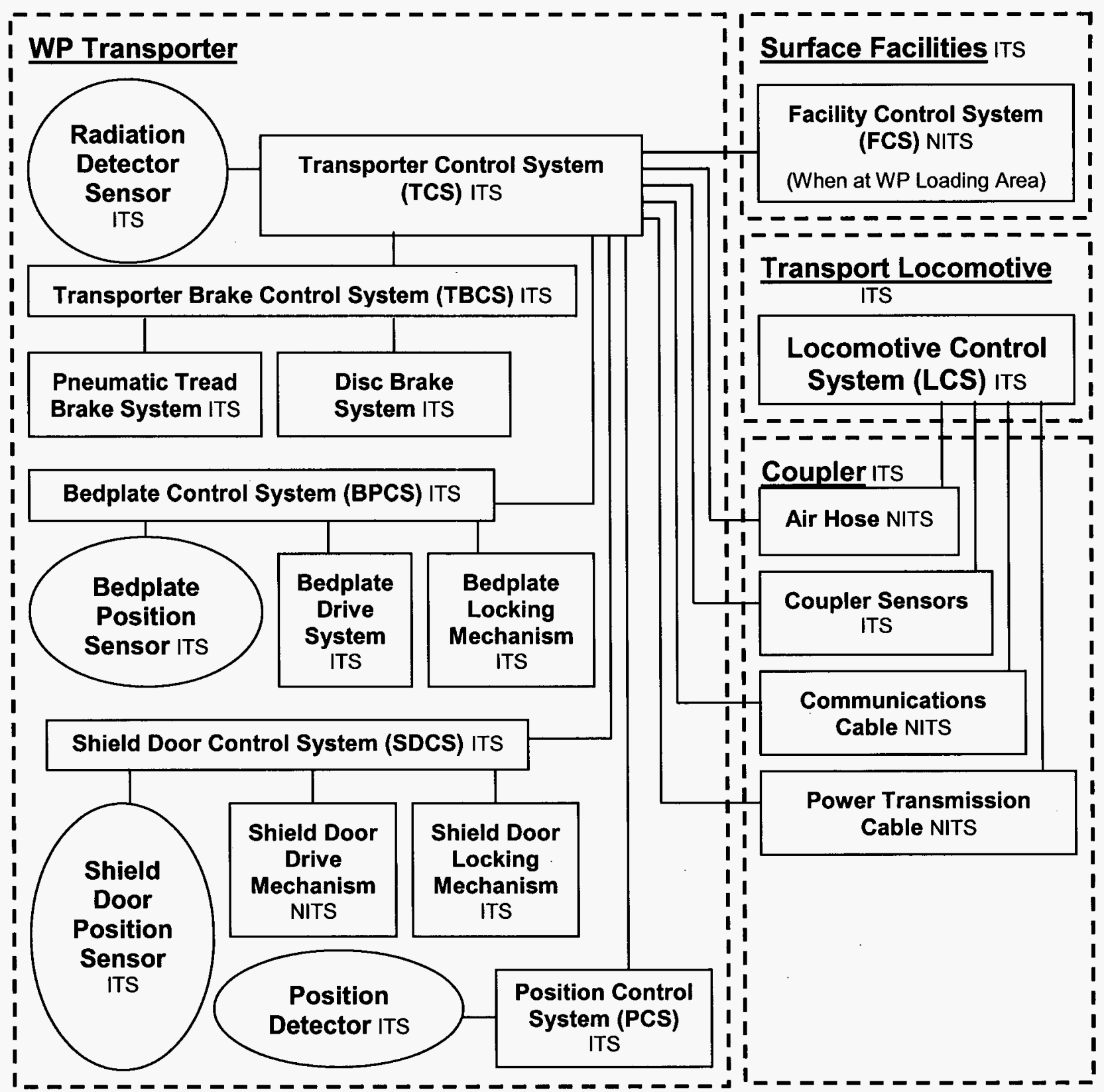

Figure 4.4.2-1: Alternative 2 WP Transporter Basic Control Block Diagram 


\section{ITS REQUIREMENTS FOUND}

The ITS requirements that were identified in this study were directly taken out of the Nuclear Safety Design Basis for License Application (BSC 2005). There were no additional ITS requirements identified other than the thirteen ITS requirements listed in the Nuclear Safety Design Basis for License Application (BSC 2005). See Section 8 for a listing of other documents reviewed.

\subsection{REQUIREMENTS}

Each requirement that was identified in the NSDB has been assigned its own requirement number, and is highlighted in an italic font, in this document.

\subsubsection{Requirement 1}

"The WP Transporter shall transport the WP in a manner such that if a collision or derailment (excluding tipover) occurs, the WP impact energy will be low enough to preclude a WP breach; this impact energy translates into a maximum WP Transporter speed of 15 mph" (BSC 2005, Table A-II).

Since the transporter shall not exceed the speed of $15 \mathrm{mph}$, the following are ITS functions: speed detection, speed limiting/braking, and the coupler connection and detection. The coupler connection and detection is ITS because the locomotive assists in the speed limiting/braking function and therefore must remain coupled to the WP Transporter. The SSC performing the speed detection function is a speed sensor. The SSCs performing the speed limiting/braking function are the dynamic braking (Alternative 1 only), the pneumatic tread brake system, and the disc brake system (Alternative 2 only). The SSC performing the ITS function for the coupler connection detection is the coupler sensor. With these SSCs, the interlocking controls also have to be ITS. The SCS receives information from the speed sensor and activates the dynamic braking if the maximum speed is exceeded. If the excessive speed is continued, the TCS and LCS then activates the brakes through the LBCS and TBCS. Table 5.1.1-1 and Table 5.1.1-2 contains the identified SSCs and ITS functions. 
Table 5.1.1-1: Transport Locomotive Identified ITS Functions

\begin{tabular}{|l|l|l|}
\hline \multicolumn{1}{|c|}{ SSC } & \multicolumn{1}{c|}{ ITS Function } & Code and Standard Reference \\
\hline Transport Locomotive Control System & Locomotive Interlocking Controls & Section 6.1.1 \\
\hline Speed Control System & $\begin{array}{l}\text { Speed Control Interlocking } \\
\text { Controls }\end{array}$ & Section 6.1.1.1 \\
\hline Speed Sensor & Speed Detection & Section 6.1.1.1 \\
\hline $\begin{array}{l}\text { Dynamic Braking Control System } \\
\text { (Alternative 1 Only) }\end{array}$ & Speed Limiting & Section 6.1.1.1 \\
\hline $\begin{array}{l}\text { Transport Locomotive Brake Control } \\
\text { System }\end{array}$ & Brake Interlocking Controls & Section 6.1.1.2 \\
\hline Pneumatic Tread Brake Systems & Braking & Section 6.1.1.2.1 \\
\hline Disc Brake Systems (Alternative 2 Only) & Braking & Section 6.1.1.2.2 \\
\hline Coupler \& Coupler Sensor & Coupler Connection \& Detection & Section 6.1.1.3 \\
\hline
\end{tabular}

Table 5.1.1-2: WP Transporter Identified ITS Functions

\begin{tabular}{|l|l|l|}
\hline \multicolumn{1}{|c|}{ SSC } & \multicolumn{1}{|c|}{ ITS Function } & Code and Standard Reference \\
\hline WP Transporter Control System & Transporter Interlocking Controls & Section 6.2.1 \\
\hline WP Transporter Brake Control System & Brake Interlocking Controls & Section 6.2.1.1 \\
\hline Pneumatic Tread Brake System & Braking & Section 6.2.1.1.1 \\
\hline Disc Brake System (Alternative 2 Only) & Braking & Section 6.2.1.1.2 \\
\hline Coupler \& Coupler Sensor & Coupler Connection \& Detection & Section 6.2.1.2 \\
\hline
\end{tabular}

\subsubsection{Requirement 2}

"The WP Transporter shall transport the WP in a manner such that if a collision or derailment leading to a WP Transporter tipover occurs, the WP impact energy will be low enough to preclude a WP breach" (BSC 2005, Table A-II).

The height at which the WP is transported is ITS to ensure that in the event of a tipover the WP impact energy with the grade will be low enough to preclude a WP breach. This will be addressed later during the gap analysis. Table 5.1.2-1 contains the identified SSC and ITS functions. 
Table 5.1.2-1: WP Transporter Identified ITS Function

\begin{tabular}{|c|l|l|}
\hline \multicolumn{1}{|c|}{ SSC } & \multicolumn{1}{|c|}{ ITS Function } & $\begin{array}{c}\text { Code and } \\
\text { Standard } \\
\text { Reference }\end{array}$ \\
\hline WP Transporter Design & Height at which the WP is transported & None \\
\hline
\end{tabular}

\subsubsection{Requirement 3}

"While on the surface, the WP transporter shall be designed to function in extreme straight wind (90 mph)" (BSC 2005, Table A-II).

In extreme straight wind, the SSCs must maintain their safety function. Therefore, the design must contain barriers to protect the SSCs and will be addressed later in the gap analysis. Table 5.1.3-1 contains the identified SSC and ITS functions.

Table 5.1.3-1: WP Transporter Identified ITS Function

\begin{tabular}{|l|l|l|}
\hline \multicolumn{1}{|c|}{ SSC } & \multicolumn{1}{|c|}{ ITS Function } & \multicolumn{1}{|c|}{$\begin{array}{c}\text { Code and } \\
\text { Standard } \\
\text { Reference }\end{array}$} \\
\hline External Body Surface & Protection of SSC equipment & None \\
\hline Suspension Design & Maintain Safety function during high wind & Section 6.2 .3 \\
\hline
\end{tabular}

\subsubsection{Requirement 4}

"The WP Transporter and its bedplate shall not collide with a WP on the WP turntable and cause a WP breach" (BSC 2005, Table A-II).

To prevent a collision with the WP on the WP turntable, the following are ITS functions: transporter / bedplate limit switches, and the braking. The SSC performing the transporter limit switch function is a position sensor. The SSC performing the bedplate limit switch function is a bedplate position sensor. The SSCs performing the braking function are the pneumatic tread brake subsystem, and the disc brake subsystem (Alternative 2 only). With these SSCs, the interlocking controls also have to be ITS. Table 5.1.4-1 and Table 5.1.4-2 contains the identified SSCs and ITS functions. 
Table 5.1.4-1: Transport Locomotive Identified ITS Functions

\begin{tabular}{|l|l|l|}
\hline \multicolumn{1}{|c|}{ SSC } & \multicolumn{1}{c|}{ ITS Function } & Code and Standard Reference \\
\hline Transport Locomotive Control System & Locomotive Interlocking Controls & Section 6.1.1 \\
\hline $\begin{array}{l}\text { Transport Locomotive Brake Control } \\
\text { System }\end{array}$ & Brake Interlocking Controls & Section 6.1.1.2 \\
\hline Pneumatic Tread Brake Systems & Braking & Section 6.1.1.2.1 \\
\hline Disc Brake Systems (Alternative 2 Only) & Braking & Section 6.1.1.2.2 \\
\hline
\end{tabular}

Table 5.1.4-2: WP Transporter Identified ITS Functions

\begin{tabular}{|l|l|l|}
\hline \multicolumn{1}{|c|}{ SSC } & \multicolumn{1}{c|}{ ITS Function } & Code and Standard Reference \\
\hline WP Transporter Control System & Interlock Controls & Section 6.2.1 \\
\hline Position Control System & Interlock Controls & Section 6.2.1.5 \\
\hline Positon Sensor & Position Locator & Section 6.2.1.5.1 \\
\hline WP Transporter Brake Control System & Interlock Controls & Section 6.2.1.1 \\
\hline Pneumatic Tread Brake System & Braking & Section 6.2.1.1.1 \\
\hline Disc Brake System (Alternative 2 Only) & Braking & Section 6.2.1.1.2 \\
\hline Bedplate Control System & Interlock Controls & Section 6.2.1.3 \\
\hline Bedplate Position Sensor & Limit Switch & Section 6.2.1.3.2 \\
\hline
\end{tabular}

\subsubsection{Requirement 5}

"The rate of a WP Transporter runaway shall be less than $8.3 \times 10^{-9}$ runaways per trip" (BSC 2005, Table A-II).

To prevent WP transporter runaway, the following are ITS functions: speed detection, speed limiting/braking, and the coupler connection and detection. The SSC performing the speed detection function is a speed sensor. The SSCs performing the speed limiting/braking functions are the dynamic braking (Alternative 1 only), the pneumatic tread brake system, and the disc brake system (Alternative 2 only). The coupler sensors are the SSCs that sense the coupler connection. With these SSCs, the interlocking controls also have to be ITS. The SCS receives information from the speed sensor and activates the dynamic braking if the maximum speed is exceeded. If the excessive speed is continued, the TCS and LCS then activates the brakes through the LBCS and TBCS. Table 5.1.5-1 and Table 5.1.5-2 contains the Identified SSCs and functions. 
Table 5.1.5-1: Transport Locomotive Identified ITS Functions

\begin{tabular}{|l|l|l|}
\hline \multicolumn{1}{|c|}{ SSC } & \multicolumn{1}{c|}{ ITS Function } & Code and Standard Reference \\
\hline Transport Locomotive Control System & Locomotive Interlocking Controls & Section 6.1.1 \\
\hline Speed Control System & $\begin{array}{l}\text { Speed Control Interlocking } \\
\text { Controls }\end{array}$ & Section 6.1.1.1 \\
\hline Speed Sensor & Speed Detection & Section 6.1.1.1 \\
\hline $\begin{array}{l}\text { Dynamic Braking Control System } \\
\text { (Alternative 1 Only) }\end{array}$ & Speed Limiting & Section 6.1.1.1 \\
\hline $\begin{array}{l}\text { Transport Locomotive Brake Control } \\
\text { System }\end{array}$ & Brake Interlocking Controls & Section 6.1.1.2 \\
\hline Pneumatic Tread Brake Systems & Braking & Section 6.1.1.2.1 \\
\hline Disc Brake Systems (Alternative 2 Only) & Braking & Section 6.1.1.2.2 \\
\hline Coupler \& Coupler Sensor & Coupler Connection \& Detection & Section 6.1.1.3 \\
\hline
\end{tabular}

Table 5.1.5-2: WP Transporter Identified ITS Functions

\begin{tabular}{|l|l|l|}
\hline \multicolumn{1}{|c|}{ SSC } & \multicolumn{1}{|c|}{ ITS Function } & Code and Standard Reference \\
\hline WP Transporter Control System & Transporter Interlocking Controls & Section 6.2.1 \\
\hline WP Transporter Brake Control System & Brake Interlocking Controls & Section 6.2.1.1 \\
\hline Pneumatic Tread Brake System & Braking & Section 6.2.1.1.1 \\
\hline Disc Brake System (Alternative 2 Only) & Braking & Section 6.2.1.1.2 \\
\hline Coupler \& Coupler Sensor & Coupler Connection \& Detection & Section 6.2.1.2 \\
\hline
\end{tabular}

\subsubsection{Requirement 6}

"The WP Transporter (together with the locomotive and coupler) shall be designed to prevent runaway of the WP Transporter for loading conditions associated with a DBGM-2 seismic event. In addition, an analysis shall demonstrate that the WP Transporter (together with the locomotive and coupler) has sufficient seismic design margin to ensure that a "no runaway" safety function is maintained for loading conditions associated with a BDBGM seismic event" (BSC 2005, Table A-II).

To prevent WP transporter runaway from the DBGM-2 seismic event, the following are ITS functions: speed detection, speed limiting/braking, and the coupler connection detection. The speed detection ITS function is performed by the speed sensors. The speed limiting/braking ITS function is performed by the SCS, the dynamic braking (Alternative 1), the pneumatic tread braking, and the disc braking (Alternative 2). The coupler sensors are the SSCs that sense the coupler connection. With these SSCs, the interlocking controls also have to be ITS. The SCS receives information from the speed sensor and activates the dynamic braking if the maximum speed is exceeded. If the excessive speed is continued, the TCS and LCS then activates the braking through the LBCS and TBCS. Table 5.1.6-1 and Table 5.1.6-2 contains the Identified SSCs and functions. 
Table 5.1.6-1: Transport Locomotive Identified ITS Functions

\begin{tabular}{|l|l|l|}
\hline \multicolumn{1}{|c|}{ SSC } & \multicolumn{1}{|c|}{ ITS Function } & Code and Standard Reference \\
\hline Transport Locomotive Control System & Locomotive Interlocking Controls & Section 6.1.1 \\
\hline Speed Control System & $\begin{array}{l}\text { Speed Control Interlocking } \\
\text { Controls }\end{array}$ & Section 6.1.1.1 \\
\hline Speed Sensor & Speed Detection & Section 6.1.1.1 \\
\hline $\begin{array}{l}\text { Dynamic Braking Control System } \\
\text { (Alternative 1 Only) }\end{array}$ & Speed Limiting & Section 6.1.1.1 \\
\hline $\begin{array}{l}\text { Transport Locomotive Brake Control } \\
\text { System }\end{array}$ & Brake Interlocking Controls & Section 6.1.1.2 \\
\hline Pneumatic Tread Brake Systems & Braking & Section 6.1.1.2.1 \\
\hline Disc Brake Systems (Alternative 2 Only) & Braking & Section 6.1.1.2.2 \\
\hline Coupler \& Coupler Sensor & Coupler Connection \& Detection & Section 6.1.1.3 \\
\hline
\end{tabular}

Table 5.1.6-2: WP Transporter Identified ITS Functions

\begin{tabular}{|l|l|l|}
\hline \multicolumn{1}{|c|}{ SSC } & \multicolumn{1}{|c|}{ ITS Function } & Code and Standard Reference \\
\hline WP Transporter Control System & Transporter Interlocking Controls & Section 6.2.1 \\
\hline WP Transporter Brake Control System & Brake Interlocking Controls & Section 6.2.1.1 \\
\hline Pneumatic Tread Brake System & Braking & Section 6.2.1.1.1 \\
\hline Disc Brake System (Alternative 2 Only) & Braking & Section 6.2.1.1.2 \\
\hline Coupler \& Coupler Sensor & Coupler Connection \& Detection & Section 6.2.1.2 \\
\hline
\end{tabular}

\subsubsection{Requirement 7}

"The WP Transporter shall be designed for loading conditions associated with a DBGM-1 level seismic event and demonstrate sufficient margin to a "shielding integrity remains intact" safety function" (BSC 2005, Table A-II).

With a DBGM-1 level seismic event, the shielding integrity must remain intact. The WP transporter shielded compartment, shield doors, shield door hinges, and shield door locking mechanism must be designed and constructed to provide the required shielding after a DBGM-1 level seismic event. Table 5.1.7-1 contains the Identified SSCs and ITS function. 
Table 5.1.7-1: WP Transporter Identified ITS Function

\begin{tabular}{|l|l|l|}
\hline \multicolumn{1}{|c|}{ SSC } & \multicolumn{1}{|c|}{ ITS Function } & Code and Standard Reference \\
\hline Shielded Compartment & Shielding Integrity & Section 6.2.2 \\
\hline Shielded Compartment Doors & Shielding Integrity & Section 6.2.2 \\
\hline Shield Door Locking Mechanism & Shield Doors Restraint & Section 6.2.1.4.1 \\
\hline Shielded Compartment Door Hinges & Shield Doors Restraint & Section 6.2.1.4.2 \\
\hline
\end{tabular}

\subsubsection{Requirement 8}

"The transporter shielded compartment shall withstand any fall of failed ground support materials, as well as a set of rockfalls having a total mass of $5.4 \mathrm{MT}$, without jeopardizing the structural integrity of the WP" (BSC 2005, Table A-II).

After a rockfall/failed ground support event, the structural integrity must remain intact. The WP transporter shielded compartment and shield doors must be designed and constructed to provide the required structural protection for the WP after a rockfall/failed ground support event (with a total mass of 5.4 MT). Table 5.1.8-1 contains the Identified SSCs and ITS function.

Table 5.1.8-1: WP Transporter Identified ITS Function

\begin{tabular}{|l|l|l|}
\hline \multicolumn{1}{|c|}{ SSC } & \multicolumn{1}{c|}{ ITS Function } & Code and Standard Reference \\
\hline Shielded Compartment & Structural Integrity & Section 6.2.2 \\
\hline Shielded Compartment Doors & Structural Integrity & Section 6.2.2 \\
\hline
\end{tabular}

\subsubsection{Requirement 9}

"Movement of the WP transporter shielded enclosure doors shall not breach the WP or cause it to fall from the bedplate of the transporter" (BSC 2005, Table A-II).

During the loading or unloading, protection for the WP colliding with the shield doors is needed. The ITS functions must prevent the shield doors from closing until the bedplate is fully retracted and preventing bedplate extention while the shield doors are closed. Therefore, the ITS functions are detecting bedplate position and shield doors positions. With these identified SSCs the interlocking controls also have ITS functions. The BPCS receives data from the Bedplate Position Sensor. The SDCS receives data from the Shield Door Position Sensor. The TCS interlocks the BPCS with SDCS. Table 5.1.9-1 contains the Identified SSCs and ITS functions. 
Table 5.1.9-1: WP Transporter Identified ITS Function

\begin{tabular}{|l|l|l|}
\hline \multicolumn{1}{|c|}{ SSC } & \multicolumn{1}{c|}{ ITS Function } & Code and Standard Reference \\
\hline WP Transporter Control System & Transporter Interlocking Controls & Section 6.2.1 \\
\hline Bedplate Control System & Bedplate Interlocking Controls & Section 6.2.1.3 \\
\hline Bedplate Position Sensor & Detecting Bedplate Position & Section 6.2.1.3.2 \\
\hline Shield Door Control System & $\begin{array}{l}\text { Shield Doors Interlocking } \\
\text { Controls }\end{array}$ & Section 6.2.1.4 \\
\hline Shield Door Position Sensors & Detecting Shield Door Position & Section 6.2.1.4.3 \\
\hline
\end{tabular}

\subsubsection{Requirement 10}

"The restraints used to immobilize the bedplate inside the shielded compartment of the WP Transporter and the mechanism for locking the doors of the shielded compartment shall withstand a collision or derailment (including tipover) of the transporter without resulting in a Category 1 or Category 2 event sequence" (BSC 2005, Table A-II).

During transport of the WP, restraints are required to immobilize the bedplate. Also, prevention of the shielded doors opening during a collision or derailment (including tipover). The ITS functions are restraining the shield door, bedplate and WP, which are accomplished with the shield door locking mechanism, shield door hinges, bedplate locking mechanisms, shielded compartment doors and shielded compartment. With these identified SSCs the interlocking controls also have ITS functions. The TCS sends information to the BPCS and SDCS for activating the Bedplate / Shield Door Locking Mechanisms. In turn, the BPCS and SDCS activate the Bedplate / Shield Door Locking Mechanisms. Table 5.1.10-1 contains the Identified SSCs and ITS functions.

Table 5.1.10-1: WP Transporter Identified ITS Function

\begin{tabular}{|l|l|l|}
\hline \multicolumn{1}{|c|}{ SSC } & \multicolumn{1}{|c|}{ ITS Function } & Code and Standard Reference \\
\hline WP Transporter Control System & Transporter Interlocking Controls & Section 6.2.1 \\
\hline Bedplate Control System & Bedplate Interlocking Controls & Section 6.2.1.3 \\
\hline Bedplate Locking Mechanism & Bedplate Restraint & Section 6.2.1.3.1 \\
\hline Shield Door Control System & $\begin{array}{l}\text { Shield Doors Interlocking } \\
\text { Controls }\end{array}$ & Section 6.2.1.4 \\
\hline Shield Door Locking Mechanism & Shield Doors Restraint & Section 6.2.1.4.1 \\
\hline Shield Door Hinges & Shield Doors Restraint & Section 6.2.1.4.2 \\
\hline Shielded Compartment & Shielding and WP Restraint & Section 6.2.2 \\
\hline Shielded Compartment Doors & Shielding and WP Restraint & Section 6.2.2 \\
\hline
\end{tabular}




\subsubsection{Requirement 11}

"Spurious or operator-induced opening of the WP shielded compartment followed by a bedplate roll-out shall be precluded when the transporter is in motion" (BSC 2005, Table A-II).

During transport of the WP, operator-induced opening of the WP shielded compartment and bedplate extraction should be precluded. The ITS function is restricting areas, by position sensors, detecting where the shield doors can open. With these identified SSCs the interlocking controls also have ITS functions. The TCS receives information from the PCS and permits the opening of the shield doors. The PCS receives information from the position sensor and determines the location of the WP Transporter. Table 5.1.11-1 contains the Identified SSCs and ITS functions.

Table 5.1.11-1: WP Transporter Identified ITS Function

\begin{tabular}{|l|l|l|}
\hline \multicolumn{1}{|c|}{ SSC } & \multicolumn{1}{|c|}{ ITS Function } & Code and Standard Reference \\
\hline WP Transporter Control System & Transporter Interlocking Controls & Section 6.2.1 \\
\hline Position Control System & Position Interlocking Controls & Section 6.2.1.5 \\
\hline Position Sensor & Position Locator & Section 6.2.1.5.1 \\
\hline
\end{tabular}

\subsubsection{Requirement 12}

"Radiation exposure to workers due to inadvertent actuation of the WP transporter shielded compartment doors shall be precluded such that this is not a Category 1 event" (BSC 2005, Table A-II).

Inadvertent actuation of the WP shielded doors should be precluded such that it is not a Category 1 event. Therefore, the ITS function is restricting areas where the shield doors can open when a radioactive source is present. Also, preventing the shield doors opening in maintenance areas with a radiation source within the shielded compartment. Therefore, the ITS functions are the position locator and radiation source detection. The position sensor performs the position locator function; and the radiation detector performs the radiation source detection function. With these SSCs, the interlocking controls also have ITS functions. The TCS receives information from the PCS and the radiation detector and permits the opening of the shield doors. The PCS receives information from the position sensor and determines the location of the WP Transporter. Table 5.1.12-1 contains the Identified SSCs and ITS functions.

Table 5.1.12-1: WP Transporter Identified ITS Function

\begin{tabular}{|l|l|l|}
\hline \multicolumn{1}{|c|}{ SSC } & \multicolumn{1}{|c|}{ ITS Function } & Code and Standard Reference \\
\hline WP Transporter Control System & Transporter Interlocking Controls & Section 6.2.1 \\
\hline Position Control System & Position Interlocking Controls & Section 6.2.1.5 \\
\hline Position Sensor & Position Locator & Section 6.2.1.5.1 \\
\hline Radiation Detector & Radiation Source Detection & Section 6.2.1.6 \\
\hline
\end{tabular}




\subsubsection{Requirement 13}

"Upon a loss of power, the WP Transporter shall be designed to stop, retain the load, and enter a locked mode; upon a restoration of power, the WP Transporter shall stay in the locked mode until operator action is taken" (BSC 2005, Table A-II).

Upon loss of power, the ITS function is braking. The SSCs performing the braking function are the pneumatic tread brake system and the disc brake system (Alternative 2 only): The Transport Locomotive and WP Transporter automatically enter fail safe condition. For example, during power loss the brakes automatically engage. Upon power restoration, operator action must be performed to reset and restart the Transport Locomotive and WP Transporter motion. Table 5.1.13-1 and Table 5.1.13-2 contains the Identified SSCs and ITS functions.

Table 5.1.13-1: Transport Locomotive Identified ITS Functions

\begin{tabular}{|l|l|l|}
\hline \multicolumn{1}{|c|}{ SSC } & \multicolumn{1}{|c|}{ ITS Function } & Code and Standard Reference \\
\hline Pneumatic Tread Brake Systems & Braking & Section 6.1.1.2.1 \\
\hline Disc Brake Systems (Alternative 2 Only) & Braking & Section 6.1.1.2.2 \\
\hline
\end{tabular}

Table 5.1.13-2: WP Transporter Identified ITS Functions

\begin{tabular}{|l|l|l|}
\hline \multicolumn{1}{|c|}{ SSC } & \multicolumn{1}{|c|}{ ITS Function } & Code and Standard Reference \\
\hline Pneumatic Tread Brake System & Braking & Section 6.2.1.1.1 \\
\hline Disc Brake System (Alternative 2 Only) & Braking & Section 6.2.1.1.2 \\
\hline
\end{tabular}




\section{IDENTIFIED ITS CODES AND STANDARDS}

In order to capture all of the codes and standards an exhaustive study was performed. This study consisted of an evaluation of industry consensus codes and standards to identify applicability to the ITS SSCs. Refer to Section 8.5 for a list of codes, standards, regulations, and directives reviewed for this section. The codes and standards selected were based upon their applicability to the requirements of the ITS SSCs, in particular within a nuclear environment. The evaluation of the identified industry codes and standards (see section 7.2 for a list of identified Industry Codes and Standards) looked at the applicable sections of each code and standard. This was done to ensure that the design, construction, installation, testing, and operations were all analyzed to show how each of the particular SSC will satisfy the ITS requirements.

Note: The extent of the applicability of each code and standard identified will be further defined through the completion of a subsequent gap analysis study.

\subsection{TRANSPORT LOCOMOTIVE}

\subsubsection{Transport Locomotive Control System}

The codes and standards listed in Table 6.1.1-1 will be used in their entirety. The locomotive control system (LCS) provides the operator local control console, and radio frequency (RF) communications to the operators in the main control system (MCS) (see Figure 4.3.1-1 and Figure 4.3.2-1). The LCS interfaces to the SCS, LBCS, power transmission, and communication with the transporter though an umbilical communications cable attached to the transporter. The LCS will contain the functional and design requirements established in IEEE Std 603-1998, and IEEE Std 7-4.3.2-2003 for the instrumentation and control portions of the LCS. The additional IEEE and ANSI/ISA Standards will provide the installation/mounting, independence, setpoints, single failure criteria, and qualification requirements for the system.

Table 6.1.1-1 is a list of applicable codes and standards for the Locomotive Control System. 
Table 6.1.1-1: Transport Locomotive Control System Applicable Codes and Standards

\begin{tabular}{|l|l|l|}
\hline $\begin{array}{l}\text { Applicable Code or } \\
\text { Standard }\end{array}$ & Sections & \multicolumn{1}{c|}{ Title } \\
\hline $\begin{array}{l}\text { ANSI/IEEE Std 344- } \\
1987^{*}\end{array}$ & Entire & $\begin{array}{l}\text { IEEE Recommended Practice for Seismic Qualification of Class 1E } \\
\text { Equipment for Nuclear Power Generating Stations }\end{array}$ \\
\hline $\begin{array}{l}\text { ANSI/ISA-67.01.01- } \\
2002^{*}\end{array}$ & Entire & Transducer and Transmitter Installation for Nuclear Safety Applications \\
\hline $\begin{array}{l}\text { ANSI/ISA-67.04.01- } \\
2000^{*}\end{array}$ & Entire & $\begin{array}{l}\text { Setpoints for Nuclear Safety Related Instrumentation-Formally ANSI//SA- } \\
\text { S67.04-2000 }\end{array}$ \\
\hline $\begin{array}{l}\text { IEEE Std 7-4.3.2- } \\
2003^{*}\end{array}$ & Entire & $\begin{array}{l}\text { IEEE Standard Criteria for Digital Computers in Safety Systems of Nuclear } \\
\text { Power Generating Stations }\end{array}$ \\
\hline IEEE Std 323-2003* & Entire & $\begin{array}{l}\text { IEEE Standard for Qualifying Class 1E Equipment for Nuclear Power } \\
\text { Generating Stations }\end{array}$ \\
\hline IEEE Std 379-2000* & Entire & $\begin{array}{l}\text { IEEE Standard Application of the Single-Failure Criterion to Nuclear Power } \\
\text { Generating Station Safety Systems }\end{array}$ \\
\hline IEEE Std 384-1992* & Entire & Standard Criteria for Independence of Class 1E Equipment and Circuits \\
\hline IEEE Std 603-1998* & Entire & Standard Criteria for Safety Systems in Nuclear Power Generating Stations \\
\hline
\end{tabular}

* These nuclear standards apply for nuclear power industry and may not necessarily apply to rail SSCs.

\subsubsection{Transport Locomotive Speed Control System}

This section is applicable in Alternative 1 only. Even though standard AAR 2004, Section M Standard S-5018 is specific to diesel-electric locomotives, some of the principles presented may be applicable to an electric locomotive. It is however, the only established railroad standard for dynamic braking. Further analysis needs to be performed and dynamic braking will be addressed later within the gap analysis.

The codes and standards listed in Table 6.1.1-2 will be used in their entirety. The locomotive speed control system (SCS) provides the instrumentation and speed control capability to the local operators and to the operators in the main control system (MCS) via the LCS (see Figure 4.3.1-1 and Figure 4.4.1-1). The SCS interfaces with the LCS, dynamic brake, drive system, and the speed sensor. The SCS will contain the functional and design requirements established in IEEE 603-1998 and IEEE 7-4.3.2-2003 for the instrumentation and control portions of the SCS. The additional IEEE and ANSI/ISA Standards will provide the installation/mounting, independence, setpoints, single failure criteria, and qualification requirements for the system.

For this requirement, the speed sensor and the dynamic brake subsystem are ITS. The SCS applicable codes and standards are shown in Table 6.1.1-2. 
Table 6.1.1-2: Transport Locomotive Speed Control System Applicable Codes and Standards

\begin{tabular}{|c|c|c|}
\hline $\begin{array}{l}\text { Applicable Code or } \\
\text { Standard }\end{array}$ & Sections & Title \\
\hline $\begin{array}{l}\text { AAR 2004, Section } \\
\text { M, S-5018 }\end{array}$ & Entire & Dynamic Braking Control (May not be Applicable) \\
\hline $\begin{array}{l}\text { ANSI//EEE Std 344- } \\
1987^{*}\end{array}$ & Entire & $\begin{array}{l}\text { IEEE Recommended Practice for Seismic Qualification of Class } 1 E \\
\text { Equipment for Nuclear Power Generating Stations }\end{array}$ \\
\hline $\begin{array}{l}\text { ANSI/ISA-67.01.01- } \\
2002^{*}\end{array}$ & Entire & Transducer and Transmitter Installation for Nuclear Safety Applications \\
\hline $\begin{array}{l}\text { ANSI/ISA-67.04.01- } \\
2000^{*}\end{array}$ & Entire & $\begin{array}{l}\text { Setpoints for Nuclear Safety Related Instrumentation-Formally ANSI/ISA- } \\
\text { S67.04-2000 }\end{array}$ \\
\hline $\begin{array}{l}\text { IEEE Std 7-4.3.2- } \\
2003^{*}\end{array}$ & Entire & $\begin{array}{l}\text { IEEE Standard Criteria for Digital Computers in Safety Systems of Nuclear } \\
\text { Power Generating Stations } \\
\end{array}$ \\
\hline IEEE Std 323-2003* & Entire & $\begin{array}{l}\text { IEEE Standard for Qualifying Class 1E Equipment for Nuclear Power } \\
\text { Generating Stations }\end{array}$ \\
\hline IEEE Std $379-2000^{*}$ & Entire & $\begin{array}{l}\text { IEEE Standard Application of the Single-Failure Criterion to Nuclear Power } \\
\text { Generating Station Safety Systems }\end{array}$ \\
\hline IEEE Std 384-1992* & Entire & Standard Criteria for Independence of Class 1 E Equipment and Circuits \\
\hline IEEE Std 603-1998* & Entire & Standard Criteria for Safety Systems in Nuclear Power Generating Stations \\
\hline
\end{tabular}

* These nuclear standards apply for nuclear power industry and may not necessarily apply to rail SSCs.

\subsubsection{Transport Locomotive Brake Control System}

The LBCS interfaces the pneumatic tread brake subsystem and the disc brake system (Alternative 2 Only) (See Figure 4.3.1-1 and Figure 4.4.1-1).

Braking commands issued from the LCS are interrogated by the LBCS and the appropriate braking response is sent to the brakes. Braking can be applied independently to the locomotive, the transporter, or both the locomotive and the transporter.

The LBCS will contain the functional and design requirements established in IEEE Std 6031998, and IEEE 7-4.3.2-2003 for the instrumentation and control portions of the LBCS. The additional IEEE and ANSI/ISA Standards will provide the installation/mounting, independence, Setpoints, single failure criteria, and qualification requirements for the system.

Table 6.1.1-3 lists the applicable codes and standards for the locomotive brake control systems. 
Table 6.1.1-3: Transport Locomotive Brake Control System Applicable Codes and Standards

\begin{tabular}{|l|l|l|}
\hline $\begin{array}{c}\text { Applicable Code or } \\
\text { Standard }\end{array}$ & Sections & \multicolumn{1}{c|}{ Title } \\
\hline $\begin{array}{l}\text { ANSI/IEEE Std 344- } \\
1987^{*}\end{array}$ & Entire & $\begin{array}{l}\text { IEEE Recommended Practice for Seismic Qualification of Class 1E } \\
\text { Equipment for Nuclear Power Generating Stations }\end{array}$ \\
\hline $\begin{array}{l}\text { ANSI/ISA-67.01.01- } \\
2002^{*}\end{array}$ & Entire & Transducer and Transmitter Installation for Nuclear Safety Applications \\
\hline $\begin{array}{l}\text { ANSI/ISA-67.04.01- } \\
2000^{*}\end{array}$ & Entire & $\begin{array}{l}\text { Setpoints for Nuclear Safety Related Instrumentation-Formally ANSI/ISA- } \\
\text { S67.04-2000 }\end{array}$ \\
\hline $\begin{array}{l}\text { IEEE Std 7-4.3.2- } \\
2003^{*}\end{array}$ & Entire & $\begin{array}{l}\text { IEEE Standard Criteria for Digital Computers in Safety Systems of Nuclear } \\
\text { Power Generating Stations }\end{array}$ \\
\hline IEEE Std 323-2003* & Entire & $\begin{array}{l}\text { IEEE Standard for Qualifying Class 1E Equipment for Nuclear Power } \\
\text { Generating Stations }\end{array}$ \\
\hline IEEE Std 379-2000* & Entire & $\begin{array}{l}\text { IEEE Standard Application of the Single-Failure Criterion to Nuclear Power } \\
\text { Generating Station Safety Systems }\end{array}$ \\
\hline IEEE Std 384-1992* & Entire & Standard Criteria for Independence of Class 1E Equipment and Circuits \\
\hline IEEE Std 603-1998* & Entire & Standard Criteria for Safety Systems in Nuclear Power Generating Stations \\
\hline
\end{tabular}

* These nuclear standards apply for nuclear power industry and may not necessarily apply to rail SSCs.

\subsection{Pneumatic Tread Brake Subsystem}

Contained in Table 6.1.1-4, are the railroad industry brake standards for locomotives. With the current design, numerous AAR 2004, Section M standards apply. These standards discuss the braking system design and components for locomotives. As the design progresses and equipment selection is made, many of the standards will no longer apply.

The pneumatic tread brake subsystem gets braking commands from the TBCS (see Figure 4.3.2-1 and Figure 4.4.2-1) and modulates the pneumatic cylinder pressure to gradually apply pressure to the tread brakes. The pneumatic tread brake is actuated by an electronically controlled pneumatic (ECP) brake system. The ECP brake system allows the operator to apply a graduated increase or decrease of pneumatic pressure to the braking systems. This provides a graduated braking to the locomotive and transporter. The graduated braking is controlled by a microprocessor based control system that monitors brake cylinder pressure, reservoir tank, and pipe pressure.

Table 6.1.1-4 lists the applicable codes and standards for the pneumatic tread brake subsystems. 
Table 6.1.1-4: Pneumatic Tread Brake Subsystem Applicable Codes and Standards

\begin{tabular}{|l|l|l|}
\hline $\begin{array}{l}\text { Applicable Code or } \\
\text { Standard }\end{array}$ & Sections & \multicolumn{1}{c|}{ Title } \\
\hline $\begin{array}{l}\text { AAR 2004, Section } \\
\text { M, S-5529 }\end{array}$ & Entire & Multiple Unit Pneumatic Brake Equipment for Locomotives \\
\hline $\begin{array}{l}\text { AAR 2004, Section } \\
\text { M, RP-509 }\end{array}$ & Entire & Braking Ratios \\
\hline $\begin{array}{l}\text { AAR 2004, Section } \\
\text { M, RP-518 }\end{array}$ & Entire & Brake Shoe Unflanged \\
\hline $\begin{array}{l}\text { AAR 2004, Section } \\
\text { M, RP-599 }\end{array}$ & Entire & Brake Shoes - High Friction Composition Type for Locomotives \\
\hline $\begin{array}{l}\text { AAR 2004, Section } \\
\text { M, RP-5209 }\end{array}$ & Entire & Basic Brake Design Data for Freight Locomotives \\
\hline $\begin{array}{l}\text { AAR 2004, Section } \\
\text { M, RP-5596 }\end{array}$ & Entire & Brake Shoes - Metal Type \\
\hline
\end{tabular}

\subsection{Disc Brake Subsystem (Alternative 2)}

The disc brake subsystem gets braking commands from the LBCS. Currently there are no codes and standards identified for disc braking systems. Disc brakes are typically used in passenger transit not in freight applications. This will be addressed later in the gap analysis.

Table 6.1.1-5 lists the applicable codes and standards for the disc brake subsystems.

Table 6.1.1-5: Disc Brake Subsystem Applicable Codes and Standards

\begin{tabular}{|l|l|ll|}
\hline $\begin{array}{c}\text { Applicable Code or } \\
\text { Standard }\end{array}$ & Sections & Title \\
\hline None & N/A & N/A \\
\hline
\end{tabular}

\subsubsection{Transport Locomotive Coupler}

Section 4.1.5.3 of the AAR, states that the vertical loads on the coupler must follow Paragraph 4.1.5 of AAR 2004, Section C - Part II Standard M-1001. Also Section 4.1.7.1 discusses that "the coupling system must be designed such that overriding will not occur and that the train will remain coupled together" (AAR S-2043).

The coupler between the locomotive and the transporter has a sensor that verifies that the coupler is engaged or disengaged. The sensor when disengaged commands the transporter brake system to actuate (i.e. the transporter cannot be moved when disengaged from the locomotive). The sensor is installed per the functional requirements of ANSI/ISA 67.01.01-2002. 
The couplers maintain the connection between the transport locomotive and the WP transporter (See Figure 4.3.1-1 and Figure 4.4.1-1). For this requirement, the coupler sensor connection is ITS. The Coupler applicable codes and standards are shown in Table 6.1.1-6.

Table 6.1.1-6: Transport Locomotive Coupler Applicable Codes and Standards

\begin{tabular}{|l|l|l|}
\hline $\begin{array}{c}\text { Applicable Code or } \\
\text { Standard }\end{array}$ & Sections & \multicolumn{1}{c|}{ Title } \\
\hline $\begin{array}{l}\text { AAR 2004, Section C } \\
\text { - Part II, M-1001 }\end{array}$ & 4.1 .5 & Specification for Design, Fabrication and Construction of Freight Cars \\
\hline AAR S-2043 & $\begin{array}{l}4.1 .5 .3 \\
4.1 .7 .1\end{array}$ & $\begin{array}{l}\text { Performance Specification for Trains Used to Carry High Level Radioactive } \\
\text { Material }\end{array}$ \\
\hline $\begin{array}{l}\text { ANSI/ISA 67.01.01- } \\
\text { 2002* }\end{array}$ & Entire & Transducer and Transmitter Installation for Nuclear Safety Applications \\
\hline
\end{tabular}

* This nuclear standard applies for nuclear power industry and may not necessarily apply to rail SSCs.

\subsection{WP TRANSPORTER}

\subsubsection{WP Transporter Control System (TCS)}

The TCS interfaces with the WP transporter brake control system (TBCS), bedplate control system (BPCS), shield door control system (SDCS), position control system (PCS), and the facility control system (FCS). Inputs are received from power, communications, sensors, and the radiation detector (see Figure 4.3.1-1 and Figure 4.4.2-1).

The TCS controls all activities onboard the transporter. The TCS interlocks the TBCS with the speed sensor, and locomotive (via communications cable) for excessive speed. Also, TCS interlocks the BPCS and SDCS to prevent closing of the shield doors on the WP. The TCS interlocks the radiation detection sensor, position detector, and PCS to allow the WP to be exposed only in acceptable areas (i.e. surface WP loading docks and emplacement drift docking area). The FCS communicates directly with the TCS at the surface WP loading dock (via the WP loading dock umbilical cable).

The TCS will contain the functional and design requirements established in IEEE Std 603-1998, and IEEE 7-4.3.2-2003 for the instrumentation and control portions of the TCS. The additional IEEE and ANSI/ISA Standards will provide the installation/mounting, independence, Setpoints, single failure criteria, and qualification requirements for the system.

Therefore, the TCS is ITS and Table 6.2.1-1 is a list of applicable codes and standards. 
Table 6.2.1-1: WP Transporter Control System Applicable Codes and Standards

\begin{tabular}{|l|l|l|}
\hline $\begin{array}{l}\text { Applicable Code or } \\
\text { Standard }\end{array}$ & Sections & \multicolumn{1}{c|}{ Title } \\
\hline $\begin{array}{l}\text { ANSI//EEE Std 344- } \\
1987^{*}\end{array}$ & Entire & $\begin{array}{l}\text { IEEE Recommended Practice for Seismic Qualification of Class 1E } \\
\text { Equipment for Nuclear Power Generating Stations }\end{array}$ \\
\hline $\begin{array}{l}\text { ANSI//SA-67.01.01- } \\
2002^{*}\end{array}$ & Entire & Transducer and Transmitter Installation for Nuclear Safety Applications \\
\hline $\begin{array}{l}\text { ANSI/ISA-67.04.01- } \\
2000^{*}\end{array}$ & Entire & $\begin{array}{l}\text { Setpoints for Nuclear Safety Related Instrumentation-Formally ANSI/ISA- } \\
\text { S67.04-2000 }\end{array}$ \\
\hline $\begin{array}{l}\text { IEEE Std 7-4.3.2- } \\
2003^{*}\end{array}$ & Entire & $\begin{array}{l}\text { IEEE Standard Criteria for Digital Computers in Safety Systems of Nuclear } \\
\text { Power Generating Stations }\end{array}$ \\
\hline IEEE Std 323-2003* & Entire & $\begin{array}{l}\text { IEEE Standard for Qualifying Class 1E Equipment for Nuclear Power } \\
\text { Generating Stations }\end{array}$ \\
\hline IEEE Std 379-2000* & Entire & $\begin{array}{l}\text { IEEE Standard Application of the Single-Failure Criterion to Nuclear Power } \\
\text { Generating Station Safety Systems }\end{array}$ \\
\hline IEEE Std 384-1992* & Entire & Standard Criteria for Independence of Class 1E Equipment and Circuits \\
\hline IEEE Std 603-1998* & Entire & Standard Criteria for Safety Systems in Nuclear Power Generating Stations \\
\hline
\end{tabular}

* These nuclear standards apply for nuclear power industry and may not necessarily apply to rail SSCs.

\subsubsection{WP Transporter Brake Control System}

The TBCS contains the microprocessor electronics system that performs the functions of the ECP brake system. The TBCS commands the pneumatic tread brake system and disc brake system (Alternative 2 Only) to stop the transporter. The ECP has the capability to gradually apply brake pressure or in emergency situations, to fully engage the brakes.

The TBCS gets the braking commands from the TCS via the communications cable from the locomotive on board operator (see Figure 4.3.2-1 and Figure 4.4.2-1).

The TBCS will contain the functional and design requirements established in IEEE 603-1998 and IEEE 7-4.3.2-2003 for the instrumentation and control portions of the TBCS. The additional IEEE and ANSI/ISA Standards will provide the installation/mounting, independence, Setpoints, single failure criteria, and qualification requirements for the system.

Therefore, the braking systems are ITS and the applicable codes and standards are listed in Table 6.2.1-2. 
Table 6.2.1-2: Braking Control System Applicable Codes and Standards

\begin{tabular}{|c|c|c|}
\hline $\begin{array}{l}\text { Applicable Code or } \\
\text { Standard }\end{array}$ & Sections & Title \\
\hline $\begin{array}{l}\text { AAR 2004, Section E } \\
\text { - Part II, S-4200 }\end{array}$ & Entire & $\begin{array}{l}\text { Electrically Controlled Pneumatic (ECP) Cable-Based Brake Systems - } \\
\text { Performance Requirements }\end{array}$ \\
\hline $\begin{array}{l}\text { AAR } 2004, \text { Section E } \\
\text { - Part II, S-4210 }\end{array}$ & Entire & $\begin{array}{l}\text { ECP Cable-Based Brake System Cable, Connectors, and Junction Boxes - } \\
\text { Performance Specification }\end{array}$ \\
\hline $\begin{array}{l}\text { AAR } 2004, \text { Section E } \\
\text { - Part II, S-4220 }\end{array}$ & Entire & ECP Cable-Based Brake DC Power Supply - Performance Specification \\
\hline $\begin{array}{l}\text { AAR } 2004, \text { Section E } \\
\text { - Part II, S-4230 }\end{array}$ & Entire & $\begin{array}{l}\text { Intratrain Communication Specification for Cable-Based Freight Train } \\
\text { Control Systems (Either S-4230 or S-4300) }\end{array}$ \\
\hline $\begin{array}{l}\text { AAR 2004, Section E } \\
\text { - Part II, S-4300 }\end{array}$ & Entire & $\begin{array}{l}\text { Performance Requirement for Electronically Controlled Pneumatic (ECP) } \\
\text { Radio-Based Freight Brake Systems (Either S-4200 or S-4300) }\end{array}$ \\
\hline AAR S-2043 & 4.4 & $\begin{array}{l}\text { Performance Specification for Trains Used to Carry High Level Radioactive } \\
\text { Material }\end{array}$ \\
\hline $\begin{array}{l}\text { ANSI/IEEE Std } 344- \\
1987^{*}\end{array}$ & Entire & $\begin{array}{l}\text { IEEE Recommended Practice for Seismic Qualification of Class } 1 E \\
\text { Equipment for Nuclear Power Generating Stations }\end{array}$ \\
\hline $\begin{array}{l}\text { ANSI/ISA-67.01.01- } \\
2002^{*}\end{array}$ & Entire & Transducer and Transmitter Installation for Nuclear Safety Applications \\
\hline $\begin{array}{l}\text { ANSI/ISA-67.04.01- } \\
2002^{\star}\end{array}$ & Entire & Setpoints for Nuclear Safety Related Instrumentation \\
\hline $\begin{array}{l}\text { IEEE Std 7-4.3.2- } \\
2003^{\star}\end{array}$ & Entire & $\begin{array}{l}\text { IEEE Standard Criteria for Digital Computers in Safety Systems of Nuclear } \\
\text { Power Generating Stations }\end{array}$ \\
\hline IEEE Std $323-2003^{*}$ & Entire & $\begin{array}{l}\text { IEEE Standard for Qualifying Class 1E Equipment for Nuclear Power } \\
\text { Generating Stations }\end{array}$ \\
\hline IEEE Std $379-2000^{*}$ & Entire & $\begin{array}{l}\text { IEEE Standard Application of the Single-Failure Criterion to Nuclear Power } \\
\text { Generating Station Safety Systems }\end{array}$ \\
\hline IEEE Std 384-1992* & Entire & Standard Criteria for Independence of Class $1 E$ Equipment and Circuits \\
\hline IEEE Std 603-1998* & Entire & Standard Criteria for Safety Systems in Nuclear Power Generating Stations \\
\hline
\end{tabular}

* These nuclear standards apply for nuclear power industry and may not necessarily apply to rail SSCs.

\subsection{Pneumatic Tread Brake Subsystem}

The pneumatic tread brake subsystem gets braking commands from the TBCS and modulates the pneumatic cylinder pressure to gradually apply pressure to the tread brakes. The pneumatic tread brake is actuated by an ECP brake system. The ECP brake system allows the operator to apply a graduated increase or decrease of pneumatic pressure to the braking systems. This provides a graduated braking to the locomotive and transporter. The graduated braking is controlled by a microprocessor based control system that monitors brake cylinder pressure, reservoir tank, and pipe pressure.

Stated in Section 4.4 of AAR S-2043, the brake system design must follow S-401 (AAR 2004, Section E) with exception to items specifically addressed within, and the brake analysis submittal must include all of the items listed in AAR 2004, Section C - Part II Standard M-1001, Paragraph 1.2.3.2 (AAR S-2043). The ECP brake system must follow the requirements presented 
in AAR 2004, Section E - Part II following standards S-4200 (or S-4300), S-4210, S-4220, and S-4230 (AAR S-2043, Section 4.4.1).

The pneumatic tread brake subsystems are ITS and the applicable codes and standards are listed in Table 6.2.1-3.

Table 6.2.1-3: Pneumatic Tread Brake Subsystem Applicable Codes and Standards

\begin{tabular}{|l|l|l|}
\hline $\begin{array}{c}\text { Applicable Code or } \\
\text { Standard }\end{array}$ & Sections & \multicolumn{1}{|c|}{ Title } \\
\hline $\begin{array}{l}\text { AAR 2004, Section C } \\
- \text { Part II, M-1001 }\end{array}$ & 1.2 .3 .2 & Specification for Design, Fabrication and Construction of Freight Cars \\
\hline $\begin{array}{l}\text { AAR 2004, Section E, } \\
\text { S-401 }\end{array}$ & Entire & Freight Car Brake Design Requirements \\
\hline AAR S-2043 & 4.4 & $\begin{array}{l}\text { Performance Specification for Trains Used to Carry High Level Radioactive } \\
\text { Material }\end{array}$ \\
\hline
\end{tabular}

\subsection{Disc Brake Subsystem (Alternative 2)}

The disc brake subsystem gets braking commands from the TBCS. However, currently there are no codes and standards identified for disc braking systems. Disc brakes are typically used in passenger transit not in freight applications. This will be addressed later in the gap analysis.

The disc brake subsystems are ITS and the applicable codes and standards are listed in Table 6.2.1-4.

Table 6.2.1-4: Disc Brake Subsystem Applicable Codes and Standards

\begin{tabular}{|l|l|l|}
\hline $\begin{array}{c}\text { Applicable Code or } \\
\text { Standard }\end{array}$ & Sections & \multicolumn{1}{c|}{ Title } \\
\hline AAR S-2043 & 4.4 & $\begin{array}{l}\text { Performance Specification for Trains Used to Carry High Level Radioactive } \\
\text { Material }\end{array}$ \\
\hline
\end{tabular}

\subsubsection{WP Transporter Coupler}

The WP transporter coupler contains the coupler sensors that send a signal to the TCS to verify the coupler is engaged. When the coupler sensor senses a disengaged coupler a signal is sent to set the transporter brakes. When the sensor senses an engaged coupler, a signal is sent to allow the transporter brakes to be disengaged.

Section 4.1.5.3 of the AAR S-2043, states that the Vertical Loads on the Coupler must follow Paragraph 4.1.5 of AAR 2004, Section C - Part II Standard M-1001. Also Section 4.1.7.1 discusses that "the coupling system must be designed such that overriding will not occur and that the train will remain coupled together" (AAR S-2043). 
The couplers maintain the connection between the transport locomotive and the WP transporter. Therefore, the coupler sensor connection is ITS and the applicable codes and standards are shown in Table 6.2.1-5.

Table 6.2.1-5: WP Transporter Coupler Applicable Codes and Standards

\begin{tabular}{|l|l|l|}
\hline $\begin{array}{c}\text { Applicable Code or } \\
\text { Standard }\end{array}$ & Sections & \multicolumn{1}{c|}{ Title } \\
\hline $\begin{array}{l}\text { AAR 2004, Section C } \\
\text { - Part II, M-1001 }\end{array}$ & 4.1 .5 & Specification for Design, Fabrication and Construction of Freight Cars \\
\hline $\begin{array}{l}\text { AAR 2004, Section E, } \\
\text { S-401 }\end{array}$ & Entire & Freight Car Brake Design Requirements \\
\hline AAR S-2043 & $\begin{array}{l}4.1 .5 .3 \\
4.1 .7 .1\end{array}$ & $\begin{array}{l}\text { Performance Specification for Trains Used to Carry High Level Radioactive } \\
\text { Material }\end{array}$ \\
\hline $\begin{array}{l}\text { ANSI/ISA 67.01.01- } \\
\text { 2002* }\end{array}$ & Entire & Transducer and Transmitter Installation for Nuclear Safety Applications \\
\hline
\end{tabular}

* This nuclear standard applies for nuclear power industry and may not necessarily apply to rail SSCs.

\subsubsection{Bedplate Control System}

The bedplate control system (BPCS) contains the interlock logic that prohibits the inadvertent extending or retraction of the bedplate. When inputs from the logical interlocks are met, the BPCS sends the "extend" or "retract" commands to the bedplate drive system.

The BPCS controls the movement of the bedplate. The BPCS interlocks the drive mechanism, locking mechanism, and position sensor.

The BCS will contain the functional and design requirements established in IEEE 603-1998, and IEEE 7-4.3.2-2003 for the instrumentation and control portions of the BCS. The additional IEEE and ANSI/ISA Standards will provide the installation/mounting, independence, Setpoints, single failure criteria, and qualification requirements for the system.

The BPCS is ITS and Table 6.2.1-6 is a list of applicable codes and standards. 
Table 6.2.1-6: Bedplate Control System Applicable Codes and Standards

\begin{tabular}{|l|l|l|}
\hline $\begin{array}{c}\text { Applicable Code or } \\
\text { Standard }\end{array}$ & Sections & \multicolumn{1}{|c|}{ Title } \\
\hline $\begin{array}{l}\text { ANSI/ISA-67.01.01- } \\
2002^{*}\end{array}$ & Entire & Transducer and Transmitter Installation for Nuclear Safety Applications \\
\hline $\begin{array}{l}\text { ANSI/ISA-67.04.01- } \\
2002^{*}\end{array}$ & Entire & Setpoints for Nuclear Safety Related Instrumentation \\
\hline $\begin{array}{l}\text { ANSI//EEE Std 344- } \\
1987^{*}\end{array}$ & Entire & $\begin{array}{l}\text { IEEE Recommended Practice for Seismic Qualification of Class 1E } \\
\text { Equipment for Nuclear Power Generating Stations }\end{array}$ \\
\hline $\begin{array}{l}\text { IEEE Std 7-4.3.2- } \\
2003^{*}\end{array}$ & Entire & $\begin{array}{l}\text { IEEE Standard Criteria for Digital Computers in Safety Systems of Nuclear } \\
\text { Power Generating Stations }\end{array}$ \\
\hline IEEE Std 323-2003* & Entire & $\begin{array}{l}\text { IEEE Standard for Qualifying Class 1E Equipment for Nuclear Power } \\
\text { Generating Stations }\end{array}$ \\
\hline IEEE Std 379-2000* & Entire & $\begin{array}{l}\text { IEEE Standard Application of the Single-Failure Criterion to Nuclear Power } \\
\text { Generating Station Safety Systems }\end{array}$ \\
\hline IEEE Std 384-1992* & Entire & Standard Criteria for Independence of Class 1E Equipment and Circuits \\
\hline IEEE Std 603-1998* & Entire & Standard Criteria for Safety Systems in Nuclear Power Generating Stations \\
\hline
\end{tabular}

* These nuclear standards apply for nuclear power industry and may not necessarily apply to rail SSCs.

\subsection{Bedplate Locking Mechanism}

The HLRM Cask in AAR S-2043 provides shielding from radioactive materials; likewise, the shielded compartment provides shielding from the WP. The bedplate, within the shielded compartment, supports the emplacement pallet, which serves as a cradle for the WP. Therefore per Paragraph 4.1.8 of the AAR S-2043, the bedplate locking mechanism "must have the ability to withstand any forces resulting from tie-down loads." Therefore, the bedplate locking mechanism is ITS and Table 6.2.1-7 is a list of applicable codes and standards.

Table 6.2.1-7: Bedplate Locking Mechanism Applicable Codes and Standards

\begin{tabular}{|l|l|l|}
\hline $\begin{array}{c}\text { Applicable Code or } \\
\text { Standard }\end{array}$ & Sections & \multicolumn{1}{c|}{ Title } \\
\hline AAR S-2043 & $\begin{array}{l}\text { Paragraph } \\
4.1 .8\end{array}$ & $\begin{array}{l}\text { Performance Specification for Trains Used to Carry High Level Radioactive } \\
\text { Material }\end{array}$ \\
\hline
\end{tabular}

\subsection{Bedplate Position Sensor}

The bedplate position sensor inputs the bedplate position to the interlock logic in the BPCS. Position logic will not allow the bedplate to extend if inputs from the shield door sensors, for example, do not confirm that the doors are open. The bedplate position sensor indicates whether the bedplate is fully retracted or fully extended.

The ANSI/ISA Standard will provide the installation/mounting requirements for the system.

The bedplate position sensor is ITS and Table 6.2.1-8 is a list of applicable codes and standards. 
Table 6.2.1-8: Bedplate Position Sensor Applicable Codes and Standards

\begin{tabular}{|l|l|l|}
\hline $\begin{array}{c}\text { Applicable Code or } \\
\text { Standard }\end{array}$ & Sections & \multicolumn{1}{c|}{ Title } \\
\hline $\begin{array}{l}\text { ANSI/ISA-67.01.01- } \\
2002^{*}\end{array}$ & Entire & Transducer and Transmitter Installation for Nuclear Safety Applications \\
\hline
\end{tabular}

* This nuclear standard applies for nuclear power industry and may not necessarily apply to rail SSCs.

\subsubsection{Shield Door Control System}

The shield door control system (SDCS) contains the interlock logic that prohibits the inadvertent opening or closing of the shield doors. When inputs from the logical interlocks are met, the SDCS sends the open or close commands to the shield door drive system.

The SDCS controls the movement of the shield doors. The SDCS interlocks the drive mechanism, locking mechanism, and position sensor.

The SDCS will contain the functional and design requirements established in IEEE 603-1998, and IEEE 7-4.3.2-2003 for the instrumentation and control portions of the SDCS. The additional IEEE and ANSI/ISA Standards will provide the installation/mounting, independence, Setpoints, single failure criteria, and qualification requirements for the system.

The SDCS is ITS and Table 6.2.1-9 is a list of applicable codes and standards.

Table 6.2.1-9: Shield Door Control System Applicable Codes and Standards

\begin{tabular}{|l|l|l|}
\hline $\begin{array}{c}\text { Applicable Code or } \\
\text { Standard }\end{array}$ & Sections & \multicolumn{1}{|c|}{ Title } \\
\hline $\begin{array}{l}\text { ANSI/ISA-67.01.01- } \\
2002^{*}\end{array}$ & Entire & Transducer and Transmitter Installation for Nuclear Safety Applications \\
\hline $\begin{array}{l}\text { ANSI/ISA-67.04.01- } \\
2002^{*}\end{array}$ & Entire & Setpoints for Nuclear Safety Related Instrumentation \\
\hline $\begin{array}{l}\text { ANSI/IEEE Std 344- } \\
1987^{*}\end{array}$ & Entire & $\begin{array}{l}\text { IEEE Recommended Practice for Seismic Qualification of Class 1E } \\
\text { Equipment for Nuclear Power Generating Stations }\end{array}$ \\
\hline $\begin{array}{l}\text { IEEE Std 7-4.3.2- } \\
2003^{*}\end{array}$ & Entire & $\begin{array}{l}\text { IEEE Standard Criteria for Digital Computers in Safety Systems of Nuclear } \\
\text { Power Generating Stations }\end{array}$ \\
\hline IEEE Std 323-2003* & Entire & $\begin{array}{l}\text { IEEE Standard for Qualifying Class 1E Equipment for Nuclear Power } \\
\text { Generating Stations }\end{array}$ \\
\hline IEEE Std 379-2000* & Entire & $\begin{array}{l}\text { IEEE Standard Application of the Single-Failure Criterion to Nuclear Power } \\
\text { Generating Station Safety Systems }\end{array}$ \\
\hline IEEE Std 384-1992* & Entire & Standard Criteria for Independence of Class 1E Equipment and Circuits \\
\hline IEEE Std 603-1998* & Entire & Standard Criteria for Safety Systems in Nuclear Power Generating Stations \\
\hline
\end{tabular}

* These nuclear standards apply for nuclear power industry and may not necessarily apply to rail SSCs.

\subsection{Shield Door Locking Mechanism}

The HLRM Cask in S-2043 provided shielding from radioactive materials; likewise, the shielded compartment provides shielding from the WP. Therefore AAR S-2043, Paragraph 4.1.8 
indicates, the shield door locking mechanism "must have the ability to withstand any forces resulting from tie-down loads." The shield door locking mechanism is ITS and Table 6.2.1-10 is a list of applicable codes and standards for the shield door locking mechanism.

Table 6.2.1-10: Shield Door Locking Mechanism Applicable Codes and Standards

\begin{tabular}{|l|l|l|}
\hline $\begin{array}{c}\text { Applicable Code or } \\
\text { Standard }\end{array}$ & Sections & \multicolumn{1}{c|}{ Title } \\
\hline AAR S-2043 & 4.1 .8 & $\begin{array}{l}\text { Performance Specification for Trains Used to Carry High Level Radioactive } \\
\text { Material }\end{array}$ \\
\hline
\end{tabular}

\subsection{Shield Door Hinges}

The HLRM Cask in S-2043 provided shielding from radioactive materials; likewise, the shielded compartment provides shielding from the WP. Therefore' AAR S-2043, Paragraph 4.1.8 indicates, the shield door hinges "must have the ability to withstand any forces resulting from tiedown loads." The shield door hinges are ITS and Table 6.2.1-10 is a list of applicable codes and standards for the shield door hinges.

Table 6.2.1-11: Shield Door Hinges Applicable Codes and Standards

\begin{tabular}{|l|l|l|}
\hline $\begin{array}{c}\text { Applicable Code or } \\
\text { Standard }\end{array}$ & Sections & \multicolumn{1}{c|}{ Title } \\
\hline AAR S-2043 & 4.1 .8 & $\begin{array}{l}\text { Performance Specification for Trains Used to Carry High Level Radioactive } \\
\text { Material }\end{array}$ \\
\hline AISC 1997 & Entire & Manual of Steel Construction, Allowable Stress Design \\
\hline
\end{tabular}

\subsection{Shield Door Position Sensor}

The shield door position sensor inputs the door position to the SDCS. The sensor will confirm the position of the shield doors to the SDCS control logic. The shield door position sensor indicates when the doors are full closed.

The ANSI/ISA Standard will provide the installation/mounting requirements for the sensor.

The shield door position sensors are ITS and Table 6.2.1-12 contains a list of applicable codes and standards.

Table 6.2.1-12: Shield Door Position Sensor Applicable Codes and Standards

\begin{tabular}{|l|l|l|}
\hline $\begin{array}{c}\text { Applicable Code or } \\
\text { Standard }\end{array}$ & Sections & \multicolumn{1}{c|}{ Title } \\
\hline $\begin{array}{l}\text { ANSI/ISA-67.01.01- } \\
2002^{*}\end{array}$ & Entire & Transducer and Transmitter Installation for Nuclear Safety Applications \\
\hline
\end{tabular}

* This nuclear standard applies for nuclear power industry and may not necessarily apply to rail SSCs. 


\subsubsection{Position Control System}

The position control system (PCS) interlocks the shield door control logic such that the shield doors can only be opened in safe locations. Position sensors will be embedded in strategic locations within the surface and subsurface areas such that the interlock logic will only allow the shield doors to open in those locations (e.g. in the surface loading areas, and the emplacement gantry loading dock). The PCS permits the TCS to expose a radiation source in safe areas only.

The PCS will contain the functional and design requirements established in IEEE 603-1998, and IEEE 7-4.3.2-2003 for the instrumentation and control portions of the PCS. The additional IEEE and ANSI/ISA Standards will provide the installation/mounting, independence, Setpoints, single failure criteria, and qualification requirements for the system.

Therefore PCS is ITS and Table 6.2.1-13 is a list of applicable codes and standards.

Table 6.2.1-13: Position Control System Applicable Codes and Standards

\begin{tabular}{|l|l|l|}
\hline $\begin{array}{c}\text { Applicable Code or } \\
\text { Standard }\end{array}$ & Sections & \multicolumn{1}{c|}{ Title } \\
\hline $\begin{array}{l}\text { ANSI/IEEE Std 344- } \\
1987^{*}\end{array}$ & Entire & $\begin{array}{l}\text { IEEE Recommended Practice for Seismic Qualification of Class 1E } \\
\text { Equipment for Nuclear Power Generating Stations }\end{array}$ \\
\hline $\begin{array}{l}\text { ANSI/ISA-67.01.01- } \\
2002^{*}\end{array}$ & Entire & Transducer and Transmitter Installation for Nuclear Safety Applications \\
\hline $\begin{array}{l}\text { ANSI/ISA-67.04.01- } \\
2002^{*}\end{array}$ & Entire & Setpoints for Nuclear Safety Related Instrumentation \\
\hline $\begin{array}{l}\text { IEEE Std 7-4.3.2- } \\
2003^{*}\end{array}$ & Entire & $\begin{array}{l}\text { IEEE Standard Criteria for Digital Computers in Safety Systems of Nuclear } \\
\text { Power Generating Stations }\end{array}$ \\
\hline IEEE Std 323-2003* & Entire & $\begin{array}{l}\text { IEEE Standard for Qualifying Class 1E Equipment for Nuclear Power } \\
\text { Generating Stations }\end{array}$ \\
\hline IEEE Std 379-2000* & Entire & $\begin{array}{l}\text { IEEE Standard Application of the Single-Failure Criterion to Nuclear Power } \\
\text { Generating Station Safety Systems }\end{array}$ \\
\hline IEEE Std 384-1992* & Entire & Standard Criteria for Independence of Class 1E Equipment and Circuits \\
\hline IEEE Std 603-1998* & Entire & Standard Criteria for Safety Systems in Nuclear Power Generating Stations \\
\hline
\end{tabular}

* These nuclear standards apply for nuclear power industry and may not necessarily apply to rail SSCs.

\subsection{Position Sensor}

The position sensors will be embedded in a suitable location such that instrumentation on board the transporter can sense the presence of the position sensor. When the position sensor is sensed, the logic will enable the shield door controls. In the absence of a position sensor, the shield doors cannot be opened automatically or remotely.

The IEEE and ANSI/ISA Standards will provide the installation/mounting, independence, Setpoints, single failure criteria, and qualification requirements for the sensor.

The position sensor is ITS and the applicable codes and standards are shown in Table 6.2.1-14. 
Table 6.2.1-14: Position Sensor Applicable Codes and Standards

\begin{tabular}{|l|l|l|}
\hline $\begin{array}{c}\text { Applicable Code or } \\
\text { Standard }\end{array}$ & Sections & \multicolumn{1}{|c|}{ Title } \\
\hline $\begin{array}{l}\text { ANSI/IEEE Std 344- } \\
1987^{*}\end{array}$ & Entire & $\begin{array}{l}\text { IEEE Recommended Practice for Seismic Qualification of Class 1E } \\
\text { Equipment for Nuclear Power Generating Stations }\end{array}$ \\
\hline $\begin{array}{l}\text { ANSI/ISA-67.01.01- } \\
2002^{*}\end{array}$ & Entire & Transducer and Transmitter Installation for Nuclear Safety Applications \\
\hline $\begin{array}{l}\text { ANSI/ISA-67.04.01- } \\
2002^{*}\end{array}$ & Entire & Setpoints for Nuclear Safety Related Instrumentation \\
\hline IEEE Std 323-2003* & Entire & $\begin{array}{l}\text { IEEE Standard for Qualifying Class 1E Equipment for Nuclear Power } \\
\text { Generating Stations }\end{array}$ \\
\hline IEEE Std 379-2000* & Entire & $\begin{array}{l}\text { IEEE Standard Application of the Single-Failure Criterion to Nuclear Power } \\
\text { Generating Station Safety Systems }\end{array}$ \\
\hline IEEE Std 384-1992* & Entire & Standard Criteria for Independence of Class 1E Equipment and Circuits \\
\hline IEEE Std 603-1998* & Entire & Standard Criteria for Safety Systems in Nuclear Power Generating Stations \\
\hline
\end{tabular}

* These nuclear standards apply for nuclear power industry and may not necessarily apply to rail SSCs.

\subsubsection{Radiation Detection Sensor}

The purpose of the radiation detection sensor is to detect the presence of a WP within the shielded compartment. The radiation detection sensor inputs the radiation level inside the shielded compartment to the interlock logic in the TCS. A radiation source detected within the shielded compartment will not allow a manual override to open the shield doors.

The IEEE and ANSI/ISA Standards will provide the installation/mounting, independence, Setpoints, single failure criteria, and qualification requirements for the sensor.The radiation detection sensor is ITS and Table 6.2.1-15 is a list of applicable codes and standards.

Table 6.2.1-15: Radiation Detector Sensor Applicable Codes and Standards

\begin{tabular}{|c|c|c|}
\hline $\begin{array}{l}\text { Applicable Code or } \\
\quad \text { Standard }\end{array}$ & Sections & Title \\
\hline $\begin{array}{l}\text { ANSI/IEEE Std 344- } \\
1987^{*}\end{array}$ & Entire & $\begin{array}{l}\text { IEEE Recommended Practice for Seismic Qualification of Class } 1 E \\
\text { Equipment for Nuclear Power Generating Stations }\end{array}$ \\
\hline $\begin{array}{l}\text { ANSI/ISA-67.01.01- } \\
2002^{*}\end{array}$ & Entire & Transducer and Transmitter Installation for Nuclear Safety Applications \\
\hline $\begin{array}{l}\text { ANSI/ISA-67.04.01- } \\
2002^{*}\end{array}$ & Entire & Setpoints for Nuclear Safety Related Instrumentation \\
\hline IEEE Std $323-2003^{*}$ & Entire & $\begin{array}{l}\text { IEEE Standard for Qualifying Class } 1 E \text { Equipment for Nuclear Power } \\
\text { Generating Stations }\end{array}$ \\
\hline IEEE Std $379-2000^{*}$ & Entire & $\begin{array}{l}\text { IEEE Standard Application of the Single-Failure Criterion to Nuclear Power } \\
\text { Generating Station Safety Systems }\end{array}$ \\
\hline IEEE Std 384-1992* & Entire & Standard Criteria for Independence of Class $1 E$ Equipment and Circuits \\
\hline IEEE Std 603-1998* & Entire & Standard Criteria for Safety Systems in Nuclear Power Generating Stations \\
\hline
\end{tabular}

* These nuclear standards apply for nuclear power industry and may not necessarily apply to rail SSCs. 


\subsubsection{Transporter Shielded Doors and Compartment}

The HLRM Cask in S-2043 provided shielding from radioactive materials; likewise, the shielded doors and compartment provides shielding from the WP. Paragraph 4.1.8.2 requires that "...securement points on the car body must have the ability to withstand any forces resulting from the tie-down loads" (AAR S-2043).

The AISC 1997, ANSI/AISC N690-1994 and AWS D1.1/D1.1M:2004 will provide the construction of the shielded compartment. The ANSI/ANS-6.1.1-1977 and ANSI/ANS-6.4-1985 will provide the design of the shielding for the shielded compartment.

Therefore, the transporter shielded doors and compartment structure must remain intact during and after a tipover or rockfall. Also, the shielded doors and compartment must maintain the shielding integrity for the protection of personnel. The transporter shielded doors and compartment are ITS and Table 6.2.2-1, contains the applicable codes and standards.

Table 6.2.2-1: Shieided Doors and Compartment Applicable Codes and Standards

\begin{tabular}{|c|c|c|}
\hline $\begin{array}{l}\text { Applicable Code or } \\
\text { Standard }\end{array}$ & Sections & Title \\
\hline AAR S-2043 & $\begin{array}{l}\text { Paragraph } \\
4.1 .8\end{array}$ & $\begin{array}{l}\text { Performance Specification for Trains Used to Carry High Level Radioactive } \\
\text { Material }\end{array}$ \\
\hline $\begin{array}{l}\text { ANSI/AISC N690- } \\
1994^{\star}\end{array}$ & Entire & $\begin{array}{l}\text { American National Standard Specification for the Design, Fabrication, and } \\
\text { Erection of Steel Safety-Related Structures for Nuclear Facilities }\end{array}$ \\
\hline $\begin{array}{l}\text { ANSI/ANS-6.1.1- } \\
1977^{*}\end{array}$ & $\begin{array}{l}\text { Sections } 3 \\
\& 4\end{array}$ & Neutron and Gamma-Ray Flux-to-Dose-Rate Factors \\
\hline ANSI/ANS-6.4-1985* & Entire & $\begin{array}{l}\text { Guidelines on the Nuclear Analysis and Design of Concrete Radiation } \\
\text { Shielding for Nuclear Power Plants }\end{array}$ \\
\hline $\begin{array}{l}\text { AWS } \\
\text { D1.1/D1.1M:2004 }\end{array}$ & Entire & Structural Welding Code - Steel \\
\hline AISC 1997 & Entire & Manual of Steel Construction, Allowable Stress Design \\
\hline
\end{tabular}

* These nuclear standards apply for nuclear power industry and may not necessarily apply to rail SSCs.

\subsubsection{Suspension Design}

The suspension system is must be designed to remain stable in curves, turnouts, switches, etc during extreme straight winds $(90 \mathrm{mph})$. This is to reduce the likelihood of a tipover.

In Paragraphs 4.2 and 4.3 of AAR S-2043, discusses the nonstructural static and dynamic analysis requirements for the suspension. However, the AAR S-2043 does not address the suspension response during extreme straight winds $(90 \mathrm{mph})$. Therefore, this will be addressed in the gap analysis.

The suspension design is ITS and Table 6.2.3-1 is a list of applicable codes and standards. 
Table 6.2.3-1: Suspension Design Applicable Codes and Standards

\begin{tabular}{|l|l|l|}
\hline $\begin{array}{c}\text { Applicable Code or } \\
\text { Standard }\end{array}$ & Sections & \multicolumn{1}{c|}{ Title } \\
\hline AAR S-2043 & $\begin{array}{l}\text { Paragraph } \\
4.2-4.3\end{array}$ & $\begin{array}{l}\text { Performance Specification for Trains Used to Carry High Level Radioactive } \\
\text { Material }\end{array}$ \\
\hline
\end{tabular}

\section{REFERENCES}

\subsection{DOCUMENTS CITED}

BSC 2004. Waste Package Transporter Preclosure Safety Analysis. 800-MQC-HET0-00200000-00A. Las Vegas, Nevada: Bechtel SAIC Company. ACC: ENG.20040623.0002. (DIRS 169554)

BSC (Bechtel SAIC Company) 2005. Nuclear Safety Design Bases for License Application. 00030R-MGR0-00400-000-001. Las Vegas, Nevada: Bechtel SAIC Company. ACC: ENG.20050308.0004. (DIRS 171512)

DOE 2004. Quality Assurance Requirements and Description. DOE/RW-0333P, Rev. 16. Washington, D.C.: U.S. Department of Energy, Office of Civilian Radioactive Waste Management. ACC: DOC.20040907.0002. (DIRS 171539)

LP-ENG-014-BSC, Rev. 0, ICN 2. Engineering Studies. Washington, D.C.: U.S. Department of Energy, Office of Civilian Radioactive Waste Management. ACC: DOC.20040225.0003. (DIRS 168862)

LP-SI.11Q-BSC, Rev. 0, ICN 1. Software Management. Washington, D.C.: U.S. Department of Energy, Office of Civilian Radioactive Waste Management. ACC: DOC.20041005.0008. (DIRS 171923)

\subsection{CODES AND STANDARDS}

AAR S-2043. 2003. Performance Specification for Trains Used to Carry High-level Radioactive Material. Washington, D.C.: Association of American Railroads. (DIRS 166338)

AAR 2004. Manual of Standards and Recommended Practices. Washington, D.C.: Association of American Railroads. TIC: 256289. (DIRS 169910)

AISC 1997. Manual of Steel Construction, Allowable Stress Design. 9th Edition, 2nd Revision, 2nd Impression. Chicago, Illinois: American Institute of Steel Construction. TIC: 240772. (DIRS 107063) 
ANSI/AISC N690-1994. 1994. American National Standard Specification for the Design, Fabrication, and Erection of Steel Safety-Related Structures for Nuclear Facilities. Chicago, Illinois: American Institute of Steel Construction. TIC: 252734. (DIRS 158835)

ANSI/ANS-6.1.1-1977. Neutron and Gamma-Ray Flux-to-Dose-Rate Factors. La Grange Park, Illinois: American Nuclear Society. TIC: 239401. (DIRS 107016)

ANSI/ANS-6.4-1985. Guidelines on the Nuclear Analysis and Design of Concrete Radiation Shielding for Nuclear Power Plants. La Grange Park, Illinois: American Nuclear Society. TIC: 204995. (DIRS 107721)

ANSI/IEEE Std 344-1987 (Reaffirmed 1993). IEEE Recommended Practice for Seismic Qualification of Class $1 E$ Equipment for Nuclear Power Generating Stations. New York, New York: American National Standards Institute. TIC: 253538. (DIRS 159619)

ANSI/ISA-67.01.01-2002. 2002. Transducer and Transmitter Installation for Nuclear Safety Applications. Research Triangle Park, North Carolina: Instrumentation, Systems, and Automation Society. (DIRS 172965)

ANSI/ISA-67.04.01-2002. Setpoints for Nuclear Safety Related Instrumentation. Research Triangle Park, North Carolina: Instrument Society of America. (DIRS 172968)

AWS D1.1/D1.1M:2004. 2004. Structural Welding Code-Steel. 19th Edition. Miami, Florida: American Welding Society. TIC: 256262 (DIRS 170489)

IEEE Std 7-4.3.2-2003. IEEE Standard Criteria for Digital Computers in Safety Systems of Nuclear Power Generating Stations. New York, New York: Institute of Electrical and Electronics Engineers. TIC: 256291. (DIRS 170777)

IEEE Std 323-2003. 2004. IEEE Standard for Qualifying Class $1 E$ Equipment for Nuclear Power Generating Stations. New York, New York: Institute of Electrical and Electronics Engineers. TIC: 255697. (DIRS 166907)

IEEE Std 379-2000. 2001. IEEE Standard Application of the Single-Failure Criterion to Nuclear Power Generating Station Safety Systems. New York, New York: Institute of Electrical and Electronics Engineers. TIC: 255427. (DIRS 166688)

IEEE Std 384-1992. 1992. IEEE Standard Criteria for Independence of Class IE Equipment and Circuits. New York, New York: Institute of Electrical and Electronics Engineers. TIC: 237497. (DIRS 103105)

IEEE Std 603-1998. IEEE Standard Criteria for Safety Systems for Nuclear Power Generating Stations. New York, New York: The Institute of Electrical and Electronics Engineers. TIC: 242993. (DIRS 125916) 


\section{REVIEWED MATERIAL}

The following lists indicate the, Project, Documents, Drawings, and Calculations/Analysis, the Industry Codes and Standards, the Regulatory Documents, the Federal Regulations and the DOE Documents reviewed in the performance of the study.

\subsection{REVIEWED DOCUMENTS}

Seven documents were identified as the documents to be used for this study. These documents were identified as documents that had potential ITS standards that could be found. Beginning with the Transport Locomotive / WP Transporter Design Calculation a list of documents with all references pertaining to the locomotive and transporter was generated. From this list of reference documents, another sub list of references was generated. This process was continued until a list of all the documents that could potentially discuss ITS requirements had been generated.

Nuclear Safety Design Bases for License Application - 000-30R-MGR0-00400-000-001.

Waste Package Transporter Preclosure Safety Analysis. 800-MQC-HET0-00200-000-00A

Categorization of Event Sequences for License Application - 000-00C-MGR0-00800-000-00Be

Project Design Criteria - 000-3DR-MGR0-00100-000-003

Project Requirements Document - TER-MGR-MD-00001 Rev 02

Project Functional and Operational Requirements. - TDR-MGR-ME-000003 Rev 02

Emplacement and Retrieval System Description Document. - 800-3YD-HE00-00100-000-003e

\subsection{REVIEWED DRAWINGS}

The following list is the Project drawings depicting the baseline concept of the Transport Locomotive / WP Transporter:

Emplacement and Retrieval General Arrangement Locomotive - 800-MQ0-HES0-00201-00000B

Emplacement and Retrieval General Arrangement Waste Package Transporter - 800-MQ0HET0-00101-000-00B

\subsection{REVIEWED CALCULATIONS/ANALYSIS}

The following Calculations and Analysis are the Project documents used in the development of the baseline concept of the Transport Locomotive / WP Transporter.

Transport Locomotive Calculation - 800-MQC-HES0- 00100-000-00A 
Waste Package Transporter Calculation - 800-MQC-HET0- 00100-000-00B

Waste Package Transporter Shielding Design Calculation - 000-00C-HE00- 00100-000-00A

\subsection{REVIEWED SYSTEM DESCRIPTION DOCUMENT}

The following is the current revision of the System Description Document pertaining to the Transport Locomotive / WP Transporter.

Emplacement and Retrieval System Description Document - 800-3YD-HE00-00100-003e

\subsection{REVIEWED INDUSTRY CODES AND STANDARDS}

The following represents the codes, standards, regulations, and directives studied for applicability to the recognized ITS SSCs.

AAR S-2043 - Performance Specification for Trains Used to Carry High-level Radioactive Material

AAR 1997 - Manual of Standards and Recommended Practices, Section C - Part II, Specifications for Design, Fabrication and Construction of Freight Cars M-1001, Volume I

AAR 1997 - Manual of Standards and Recommended Practices, Section C - Part II, Specifications for Design, Fabrication and Construction of Freight Cars M-1001, Volume II

AAR 1997 - Manual of Standards and Recommended Practices, Section D - Truck and Truck Details

AAR 1998 - Manual of Standards and Recommended Practices, Section G - Wheels and Axles

AAR 2001 - Manual of Standards and Recommended Practices, Section C - Part II, Appendices to Section C-II, Vol. I.

AAR 2001 - Manual of Standards and Recommended Practices, Section D - Part II, Code for Side Frame and Truck Bolster Design

AAR 2002 - Manual of Standards and Recommended Practices, Section E, Part II Electronically Controlled Brake Systems

AAR 2002 - Manual of Standards and Recommended Practices: Section K, Part II - Railway Communications

AAR 2002 - Manual of Standards and Recommended Practices, Section M - Locomotives and Locomotive Equipment

AAR 2003 - Manual of Standards and Recommended Practices, Section B - Couplers \& Freight Car Draft Components 
AAR 2003 - Manual of Standards and Recommended Practices: Section E-Brakes and Brake Equipment

AAR 2003 - Manual of Standards and Recommended Practices: Section K, Part I-Railway Electronics

AISC 1997 - Seismic Provisions for Structural Steel Buildings

AISC 1997 - Manual of Steel Construction, Allowable Stress Design

ANSI/AISC N690-1994 - American National Standard Specification for the Design, Fabrication, and Erection of Steel Safety-Related Structures for Nuclear Facilities

ANSI/ANS-6.1.1-1977 - Neutron and Gamma-Ray Flux-to-Dose-Rate Factors

ANSI/ANS-6.4-1985 - Guidelines on the Nuclear Analysis and Design of Concrete Radiation Shielding for Nuclear Power Plants

ANSI/AWS D14.1-97-1998 - Welding of industrial \& Mill cranes \& other Mechanical Handling equipment

ANSI/ISA-67.01.01-2002 - Transducer and Transmitter Installation for Nuclear Safety Applications

ANSI/ISA-67.04.01-2002 - Setpoints for Nuclear Safety Related Instrumentation

ANSI-ISA-S84.01 - Application of Safety Instrumented Systems for Process Industries

AWS D1.1/D1.1M-2002 - Structural Welding Code

AWS D1.6:1999 - Structural Welding Code-Stainless Steel

IEEE Std. 7-4.3.2-2003 - IEEE Standard Criteria for Digital Computers in Safety Systems of Nuclear Power Generating Stations

IEEE Std 323-2003 - IEEE Standard for Qualifying Class IE Equipment for Nuclear Power Generating Stations

IEEE Std 344-1987 - IEEE Recommended Practice for Seismic Qualification of Class $1 E$ Equipment for Nuclear Power Generating Stations

IEEE Std 379-1994 - IEEE Standard Application of the Single-Failure Criterion to Nuclear Power Generating Station Safety Systems

IEEE 384-1992 - Standard Criteria for Independence of Class IE Equipment and Circuits

IEEE Std 603-1998 - IEEE Standard Criteria for Safety Systems for Nuclear Power Generating Stations 
UL 508-December 2, 2003-Industrial Control Equipment

UL 583-July 12, 1999- Electric Battery Powered Industrial Trucks

UL 698-March 15, 1999 - Industrial Control Equipment for Use in Hazardous (Classified) Locations

\subsection{REVIEWED REGULATORY DOCUMENTS}

NUREG-0700 (O’Hara et al. 2002), - Human-System Interface Design Review Guidelines

Regulatory Guide 8.8 - Information Relevant to Ensuring that Occupational Radiation Exposures at Nuclear Power Stations Will be as Low as is Reasonably Achievable

\subsection{REVIEWED FEDERAL REGULATIONS}

10 CFR Part 20, - Standard for Protection Against Radiation.

10 CFR Part 71, - Packaging and Transportation of Radioactive Material

29 CFR Part 1910, - Occupational Safety and Health

49 CFR Part 172, - Hazardous Material Table

49 CFR Part 173 - Shippers

49 CFR Part 220 - Railroad Communications

49 CFR Part 229 \& 238 - Locomotive Crashworthiness; Proposed Rule

49 CFR Parts 229, 231, and 232 - Brake System Safety Standards for Freight and Other NonPassenger Trains and Equipment; End-of-Train Devices; Final Rule

\subsection{REVIEWED DOE DOCUMENTS}

DOE-STD-1090-2001, - Hoisting and Rigging

DOE-HDBK-1140-2001 - Human Factors/Ergonomics Handbook 